Wright State University

CORE Scholar

Summer 2015

\title{
Exploring the Racial Divide in Education and the Labor Market through Evidence from Interracial Families
}

\author{
Peter Arcidiacono \\ Andrew Beauchamp \\ Wright State University - Main Campus, andrew.beauchamp@wright.edu \\ Marie Hull \\ Seth Sanders
}

Follow this and additional works at: https://corescholar.libraries.wright.edu/econ

Part of the Economics Commons

\section{Repository Citation}

Arcidiacono, P., Beauchamp, A., Hull, M., \& Sanders, S. (2015). Exploring the Racial Divide in Education and the Labor Market through Evidence from Interracial Families. Journal of Human Capital, 9 (2), 198-238. https://corescholar.libraries.wright.edu/econ/264

This Article is brought to you for free and open access by the Economics at CORE Scholar. It has been accepted for inclusion in Economics Faculty Publications by an authorized administrator of CORE Scholar. For more information, please contact library-corescholar@wright.edu. 


\section{Exploring the Racial Divide in Education and the Labor Market through Evidence from Interracial Families}

Peter Arcidiacono

Duke University and National Bureau of Economic Research

Andrew Beauchamp

Boston College and Wright State University

Marie Hull

Duke University and Institute for the Study of Labor (IZA)

Seth Sanders

Duke University

We examine gaps between minorities and whites in education and labor market outcomes, controlling for many covariates including maternal race. Identification comes from different reported races within the family. Estimates show two distinct patterns. First, there are no significant differences in outcomes between black and white males with white mothers. Second, large differences persist between these groups and black males with black mothers. The patterns are insensitive to alternative measures of own race and school fixed effects. Our results suggest that discrimination is not occurring on the basis of child skin color but through mother-child channels such as dialect or parenting practices.

\section{Introduction}

Differences in education, employment, and earnings between black and white Americans continue to be a social concern half a century after the

We thank Peter Gottschalk, Lisa Kahn, Kevin Lang, Derek Neal, and seminar participants at Duke University, Boston College, Brigham Young University, University of California, Davis, University of North Carolina at Greensboro, Yale University, 2011 Institute for Research on Poverty Summer Research Workshop, the 2014 American Economic Association winter meetings, and the Boston University/Boston College Green-Line Labor Seminar. This research uses data from Add Health, a program project directed by Kathleen Mullan Harris and designed by J. Richard Udry, Peter S. Bearman, and Kathleen Mullan Harris at the University of North Carolina at Chapel Hill and funded by grant P01-HD31921 from the Eunice 
passage of landmark civil rights legislation. While there has undoubtedly been some convergence, black-white gaps in outcomes remain stark. During the recent recession, black unemployment rates rose to more than double white unemployment rates. Among full-time workers, the median black male earns 80 percent less per week than his white counterpart (see US Bureau of Labor Statistics 2011a, 2011b). Recent National Assessment of Educational Progress data reveal that black students score 0.7 standard deviations lower than whites on reading and mathematics tests. To the extent that test scores reflect underlying differences in human capital accumulation, we have seen little evidence of recent convergence (Neal 2006).

Researchers across disciplines have advanced numerous theories on the sources of these gaps. In this paper, we provide new evidence that narrows the potential sources of these performance gaps using data from a longitudinal, school-based survey, the National Longitudinal Study of Adolescent Health (Add Health). The data are rich in outcome variables, family background and parenting characteristics, and (crucially for this analysis) measures of maternal race. We exploit variation from interracial families generated by separate reporting of child and maternal race, along with interviewers' assessments of race and skin tone. ${ }^{1}$ Using the linear decomposition method proposed by Gelbach (2009), we assess the relative importance of various sets of observed characteristics across a number of educational and early-life labor market outcomes.

While controlling for observables typically explains only a fraction of the black-white gap for any particular outcome, our controls explain virtually the entire gap for all the outcomes we examine for black and Hispanic boys, and they explain a larger part of the gap for girls than what is typical in the literature. While there is a role for all factors, maternal race is the single-largest factor for boys, more important than the combined effects of all other characteristics of the mother, characteristics of the father, and school quality as measured by school fixed effects.

Using maternal race as part of the decomposition raises two econometric issues and an important issue of interpretation. Econometrically, both selection into interracial families and measurement error in race are a concern. We show that while white children come from families with significantly higher incomes, are more likely to come from two-parent families, and are more likely to attend high-quality schools than either black or Hispanic children with white mothers, controlling for these observables

Kennedy Shriver National Institute of Child Health and Human Development, with cooperative funding from 23 other federal agencies and foundations. Special acknowledgment is due to Ronald R. Rindfuss and Barbara Entwisle for assistance in the original design. Information on how to obtain the Add Health data files is available on the Add Health website (http://www.cpc.unc.edu/addhealth). No direct support was received from grant P01HD31921 for this analysis.

1 Throughout, we refer to Hispanic as a "race," although it is an ethnicity, simply for the sake of brevity in referring to multiracial, mixed-ancestry, and mixed-ethnicity families. 
can account for virtually all the differences in outcomes between interracial children with white mothers and white children. ${ }^{2}$ Measurement error in either the race of the child or the race of the mother could bias our estimates, and this may be of particular concern given the low rates of interracial coupling. Our results are insensitive to using self-reported race, interviewer-reported race, and interviewer-reported measures of child's skin tone instead of child race.

Our results suggest that discrimination is not occurring on the basis of the child's skin color alone but that it must operate through characteristics associated with the race of the mother. The cultural environment for children raised by black mothers may produce characteristics that are later the source of discrimination. Grogger (2011) provides one example of this, showing that those who have distinctively black speech patterns suffer a wage penalty. The fact that maternal race better explains outcome gaps for boys than for girls is also consistent with the results of Bertrand and Pan (2013), who show that noncognitive returns to parental inputs differ markedly by gender. Beyond differences in the home environment, black mothers may also be treated differently in the school system, resulting in worse classroom assignments and less teacher attention. Further, the legacy of discrimination may have resulted in black mothers not having access to the same information regarding prenatal care and parenting practices. ${ }^{3}$ While we cannot distinguish between these different mechanisms (among many others correlated with mother's race), our results suggest that channels correlated with the race of the mother are likely to be the most fruitful in uncovering the sources of black-white inequities in education and labor market outcomes.

The rest of the paper proceeds as follows. In the following section, we discuss how our results fit into the long literature on racial inequality in education and the labor market. In Section III, we describe the Add Health data and demographic characteristics of households with children and mothers of selected race combinations. Section IV outlines our econometric methods. Section V reports differences in educational and labor market outcomes in our sample and then goes on to examine how much maternal, paternal, family, and school characteristics can explain these differences. We conduct a series of robustness checks in Section VI to confirm that race of the mother is indeed the driving factor in observed racial gaps in outcomes. Finally, we discuss the implications of our findings in Section VII.

\footnotetext{
${ }^{2}$ While Hispanic children with white mothers have demographic characteristics that lie in between whites with white mothers and Hispanics with Hispanic mothers, we show that blacks with white mothers come from families that look observationally equivalent to the families of blacks with black mothers on a number of demographic measures.

${ }^{3}$ Currie and Grogger (2002) document differences in prenatal care between blacks and whites. Currie (2005) shows that early-life health disparities translate into inequality in school readiness.
} 


\section{Background}

Over the course of the twentieth century, black and white earnings converged substantially. While many factors contributed to this trend, two of the main drivers were improvements in the level and quality of education for blacks. ${ }^{4}$ However, as differences in the amount of education between blacks and whites leveled off in the mid-1980s, so did differences in earnings, leaving a gap that has persisted for the past several decades.

This focus on educational attainment should not overshadow the importance of skills gained during (and before) formal schooling. Neal and Johnson (1996) argue that children with the same years of education can differ substantially in what they have learned. Using test scores from the Armed Forces Qualifying Test, rather than education, as a proxy for skills, they can explain most of the black-white gap in wages. Thus, much of the literature has focused on understanding why black children acquire less skill per year of schooling. The measure of "skill" most often used in empirical work is a standardized test score.

Most explanations for racial gaps in test scores fall under one of four categories: families, schools, discrimination, or genetics. We outline each in turn as our work has implications for all four channels.

The primary mechanism through which families foster growth in skills is parental human capital. Since black parents typically have lower levels of human capital relative to white parents, they may have a more limited capacity to aid in their children's skill accumulation. In addition to attaining less education on average, black parents may also have differential abilities to translate own education to child test scores (Currie and Thomas 1999). The lower levels of wealth found among black parents limit the investments they can make in their children (Altonji, Doraszelski, and Segal 2000). Home investments in children, particularly at a young age, are especially important for future test scores and thus explain some of the racial disparity (Cunha et al. 2006; Todd and Wolpin 2007). All these investment decisions are more complicated for children living outside of two-parent families, which is more common among black families.

Measures of school quality are known to vary considerably by race of the student (see Ferguson and Brown 2000). Given the local public financing of schools, families sort into neighborhoods by school quality, leading students from low-income families to attend weaker schools. Ways in which school quality differs by race include average peer ability, average teacher quality, teacher turnover, and advanced course offerings. Even within schools, students have different experiences by race. Minority students are more likely to be put on a less rigorous academic track conditional on ability, and they more often have teachers with lower qualifications (see Hanushek and Rivkin 2006).

\footnotetext{
${ }^{4}$ See Smith and Welch (1989) for historical trends in wages and education. See Card and Krueger (1992) for black-white differences in educational quality and its connection to the wage gap.
} 
The race of a child may also have a direct effect on outcomes through discrimination. For example, teachers may expect poorer performance from black students and act accordingly. Racist attitudes can influence the behavior of teachers, school administrators, and students in a variety of subtle and overt ways. Jencks and Phillips (1998) explore racial biases in the tests commonly used to assess student ability and learning. "Stereotype threat" may lead black students to perform poorly on a test when they believe the test is diagnostic of intellectual ability (Steele and Aronson 1995). ${ }^{5}$ If a student underperforms for one of these latter two reasons, he might be sorted into a less challenging learning environment, which would in turn put him on a lower skill accumulation trajectory. Finally, blacks may face discrimination of another form if their peers view performing well in school negatively (see Austen-Smith and Fryer 2005).

Finally, and most controversially, are genetic explanations. The study most related to ours directly deals with this issue. Willerman, Naylor, and Myrianthopoulos (1974) examine children of mixed-race families, both pairings of black mothers and white fathers and white mothers and black fathers. They show no cognitive differences at 8 months; if anything, children of black mothers are at an advantage at this age. However, children of white mothers have significantly higher IQs at age 4 compared to children of black mothers, suggesting that the environment for children of white mothers was more conducive to cognitive development. Relatedly, Eyferth (1961) studies out-of-wedlock children of black and white US soldiers during the post-World War II occupation of Germany. All these children were raised by their German mothers. While there was considerable prejudice against blacks in Germany at the time when Eyferth gave these children a German version of the Wechsler IQ test, children with black fathers had scores almost identical to those of children with white fathers. Since this set of children did not live in segregated neighborhoods, did not attend segregated schools, and did not have mothers who were observably different, this study helped establish that race played no direct role in IQ score differences between black and white children. ${ }^{6}$

Like Eyferth (1961) and Willerman et al. (1974), our study focuses on mothers. We argue that mothers are most often the parent primarily responsible for child rearing and show empirically that white mothers raising black children are remarkably similar to black mothers on a number of key characteristics. We compare the outcomes of black children raised by white mothers to two groups: white children raised by white mothers and black children raised by black mothers. While these divisions buy us separate identification of the effects of own race and maternal race on outcomes, the cost is that each of these measures of race is likely corre-

\footnotetext{
${ }^{5}$ Stereotype threat explanations, however, would seem unable to account for the very early emergence of black-white test score gaps (Carneiro, Heckman, and Masterov 2008). Furthermore, the Steele and Aronson paper has been generally misinterpreted, actually providing evidence against standardized tests usually being given in a threatening environment. See Sackett, Hardison, and Cullen (2004).

${ }^{6}$ These results have also been called into question because of selection into the military. See Jensen (1998) and Flynn (1999) for the debate regarding selection and representation.
} 
lated with a host of unobserved factors. Of particular concern is whether white women who have children with black men are unobservably different from other white women in ways that are relevant for their children's outcomes. Nevertheless, the relative importance of child's race and mother's race helps us focus on the set of unobserved factors that most likely account for racial differences in outcomes.

While Eyferth (1961) and Willerman et al. (1974) use parental race to narrow potential explanations for outcome gaps, there is a distinct but related literature on mixed-race children who self-identify as both black and white. ${ }^{7}$ Fryer et al. (2012) find that mixed-race children are more likely to engage in risky behaviors compared to students who label themselves as only black or only white, but their self-reported grades are no different, a finding inconsistent with our results using transcript data. Also using Add Health data, Harris and Thomas (2002) show that test scores and grade point averages (GPAs) are higher among blacks from interracial families than blacks from single-race families. We explicitly attempt to separate the effect of race of the child from the effect of race of the mother. Note also that these studies focus on self-reported mixed-race individuals. Children with mixed heritage often identify as only one race or ethnicity, leading to selection issues concerning which individuals report that they are mixed race. While the "one-drop rule" does not literally hold in US survey data, several studies find that children with one white and one black parent often identify as black. ${ }^{8}$

\section{Add Health Data}

We use data from the National Longitudinal Study of Adolescent Health (Add Health). The data are nationally representative; specifically, they are a school-based sample of seventh- to twelfth-grade students in 1995 within a randomly sampled set of 80 communities across the United States. ${ }^{9}$ The first wave of the data, collected in the academic year 1994-95, attempted to survey all individuals at the selected schools.

The data include a subsample of students whose parents were also administered a survey. These in-home interviews provide information on race of the mother as well as assessments from the Add Health Picture Vocabulary Test (AHPVT). ${ }^{10}$ Follow-up surveys were conducted in 1995-96, 20012, and 2008. Wave III (2001-2) includes transcript data, along with current education and labor market participation and wages. Wave IV (2008)

\footnotetext{
7 Ruebeck, Averett, and Bodenhorn (2009) use Add Health to differentiate mother's race from child's race, but they do not examine test score measures or labor market outcomes.

${ }^{8}$ Roth (2005) discusses how changes in the US census between 1990 and 2000 reveal the prevalence of the one-drop rule. With 2000 census data, Ruggles et al. (2010) show that 39 percent of black youths with white biological mothers identify only as black.

9 A school pair, consisting of a high school and a randomly selected feeder school (middle school or junior high school from the same district), was taken from each community.

10 The AHPVT is an abbreviated version of the Peabody Picture Vocabulary Test (PVT), a nonwritten test consisting of identifying pictures with verbal responses. It is designed to measure verbal scholastic aptitude.
} 
provides information on completed education and labor market activity. The Add Health data also contain various nonrepresentative oversamples, so throughout we use the cross-sectional probability weights provided to correct for the nonrandom sample design. ${ }^{11}$ Wave-specific weights also correct for nonresponse between waves, and evaluation of these weights has been conducted in a number of validation studies. Particularly relevant for our study, race distributions and the AHPVT scores show a bias of less that 0.5 percent after using the weights at wave III. We discuss weighting further in the Appendix. ${ }^{12}$

\section{A. Definition of Race}

We use a classification system that splits an individual's survey response into four distinct groups. If the respondent indicates that he is of Hispanic or Latino origin, then we classify him as Hispanic. If he marks that his race is black/African American but does not mark Hispanic, then we classify him as black. If he marks white but not Hispanic or black, then we classify him as white. If he marks a race category that does not fall into any of the above groups, then we classify him as other. ${ }^{13}$ Table 1 shows a crosstabulation of student and maternal race conditioning on maternal race being observed. ${ }^{14}$

\section{B. Descriptive Statistics: Inputs}

Table 2 shows how maternal characteristics vary by race of the mother and the child for wave I. We focus on families with a white mother and those with either a black or Hispanic mother. An asterisk (*) denotes differences from the white mean that are significant at the 5 percent level, and a dagger $(\dagger)$ denotes differences from the own-group mean for multiracial individuals (blacks and Hispanics). ${ }^{15}$

${ }^{11}$ One of the groups oversampled was students from highly educated black families. However, this group is small, and our results hold up with their exclusion. The sample weights correct for their overrepresentation as well.

${ }^{12}$ We use the wave-specific weights for all outcomes: wave III weights are used for the results related to GPA, wave IV weights are used for college completion and wages, and all other outcomes use the weights from wave I. In the Appendix, we focus on attrition in the AHPVT across racial groups in our estimation sample. The Carolina Population Center has produced validation studies available at http://www.cpc.unc.edu/projects/addhealth/data /guides/.

${ }^{13}$ For children we use the wave I in-home questionnaire to define race. For mothers, we use the parent questionnaire. Mother's race is then the race of the surveyed parent when that parent is female and the race of the surveyed parent's spouse (or resident mother) when the parental respondent is male.

14 The parental survey response rate in Add Health was 85 percent. There is evidence that students whose parents did not respond had lower test scores. There is no evidence that this gap is different across races with the exception of the "other" race category, which we do not include in our regression analysis. We also drop those whose survey weights are zero. These students may be included in the data because they are twins, siblings, or unrelated coresidents of a sampled student.

${ }^{15}$ Means for the group black with white mother are tested against the means for blacks by excluding black children with white mothers when calculating the black mean. A similar test is used for Hispanic children. 
TABLE 1

Student Race and Maternal Race

\begin{tabular}{|c|c|c|c|c|c|}
\hline \multirow[b]{2}{*}{ Race } & \multicolumn{4}{|c|}{ Maternal Race } & \multirow[b]{2}{*}{ Total } \\
\hline & White & Black & Hispanic & Other & \\
\hline White & 8,151 & 14 & 75 & 78 & 8,318 \\
\hline Black & 132 & 2,933 & 33 & 53 & 3,151 \\
\hline Hispanic & 319 & 35 & 2,080 & 57 & 2,491 \\
\hline Other & 121 & 22 & 33 & 807 & 983 \\
\hline Total & $\overline{8,723}$ & $\overline{3,004}$ & 2,221 & 995 & $\overline{14,943}$ \\
\hline
\end{tabular}

Note.-Both races are self-reported in separate survey instruments.

As is well known, white mothers are more educated, are wealthier, are less likely to be a single parent, and have fewer children than black mothers. What is less known is that white mothers with black children are demographically similar to black mothers in a number of respects. Average income, the probability of being on welfare, and the probability of be-

TABLE 2

Mean Mother's Characteristics

\begin{tabular}{lccccc}
\hline & \multicolumn{5}{c}{ Group } \\
\cline { 2 - 6 } & White & Black & Black with & Hispanic & Hispanic with \\
& Students & Students & White Mom & Students & White Mom \\
\hline Income $(\$ 1,000)$ & 50.4 & $30.0^{*}$ & $33.0^{*}$ & $29.8^{*}$ & $48.5^{\dagger}$ \\
& $(2.0)$ & $(2.1)$ & $(4.5)$ & $(1.6)$ & $(5.4)$ \\
On welfare & {$[7,445]$} & {$[2,558]$} & {$[120]$} & {$[1,786]$} & {$[285]$} \\
& .065 & $.193^{*}$ & .211 & $.184^{*}$ & $.112^{\dagger}$ \\
Single parent & $. .008)$ & $(.016)$ & $(.093)$ & $(.023)$ & $(.031)$ \\
& {$[8,286]$} & {$[2,998]$} & {$[131]$} & {$[2,158]$} & {$[318]$} \\
& .206 & $.564^{*}$ & $.621^{*}$ & $.291^{*}$ & .255 \\
Mother's age & $(.009)$ & $(.021)$ & $(.052)$ & $(.030)$ & $(.033)$ \\
& {$[8,306]$} & {$[3,004]$} & {$[132]$} & {$[2,165]$} & {$[319]$} \\
& 41.3 & 41.5 & 39.6 & 40.7 & 40.7 \\
Mother's schooling & $(.2)$ & $(.4)$ & $(1.1)$ & $(.3)$ & $(.5)$ \\
& {$[8,032]$} & {$[2,918]$} & {$[123]$} & {$[2,096]$} & {$[312]$} \\
Biological mother & 13.3 & $12.9^{*}$ & 13.5 & $11.1 *$ & $12.7^{* \dagger}$ \\
& $(.1)$ & $(.2)$ & $(.4)$ & $(.2)$ & $(.3)$ \\
& {$[7,808]$} & {$[2,759]$} & {$[117]$} & {$[1,943]$} & {$[291]$} \\
Household size & .914 & $.871^{*}$ & .870 & .930 & $.851^{\dagger}$ \\
& $(.005)$ & $(.010)$ & $(.040)$ & $(.008)$ & $(.033)$ \\
& {$[8,265]$} & {$[2,977]$} & {$[130]$} & {$[2,137]$} & {$[315]$} \\
& 3.33 & $3.63^{*}$ & 3.45 & $4.22^{*}$ & $3.69^{* \dagger}$ \\
Number of siblings & $(.04)$ & $(.08)$ & $(.18)$ & $(.11)$ & $(.15)$ \\
& {$[8,304]$} & {$[3,012]$} & {$[132]$} & {$[2,164]$} & {$[319]$} \\
& 1.30 & $1.47^{*}$ & 1.42 & $1.86^{*}$ & $1.51^{* \dagger}$ \\
& $(.03)$ & $(.06)$ & $(.19)$ & $(.08)$ & $(.10)$ \\
& {$[8,318]$} & {$[3,019]$} & {$[132]$} & {$[2,172]$} & {$[319]$} \\
\hline
\end{tabular}

Note.-Standard errors for means are in parentheses; sample sizes are in brackets. Means are all measured in the parent survey at wave I. Household size is coresidents at wave I, and siblings includes all nonbiological siblings coresiding.

* Significantly different from the white student mean at the 5 percent level.

$\uparrow$ Significantly different from the own minority group mean (black or Hispanic) at the 5 percent level. 
ing a single parent are similar for black students with white mothers and all black students. The one exception is years of schooling: white mothers with black children have more education than black mothers with black children. Although this difference is not significant, it is economically meaningful. ${ }^{16}$ White mothers with Hispanic children have demographic characteristics that generally fall between Hispanics and whites.

The Add Health data contain a section designed to assess the relationship of adolescents to their biological fathers. We report a series of responses at wave I by maternal race groups in table $3 .{ }^{17}$ White students generally see more involvement from their fathers, have more educated fathers, and receive more child support than black students regardless of the race of the black student's mother. One dimension on which black and white partners of black men may differ is in their bargaining power. Chiappori, Oreffice, and Quintana-Domeque (2011) show that white women who intermarry are, on average, disadvantaged (heavier and less educated) relative to other white women. We see some evidence of this since most white mothers of black children are single and receive less child support than other white mothers. For black students, no significant differences arise between black students and black students with white mothers. Although the differences are not significant, the fathers of black children with white mothers communicate less with their children and are less likely to coreside with their children compared to the fathers of black students overall.

For Hispanics, the patterns are similar. Hispanics are less likely than whites to be living with their fathers and are less likely to know anything about their fathers, regardless of the race of their mother. Hispanic children with white mothers have less involvement with fathers than Hispanics overall; they are significantly less likely to live with their fathers and to speak with them weekly. Weighed against the lower involvement, Hispanic students with white mothers have more educated fathers than other Hispanic children, and they also receive higher child support payments.

Chiappori et al. (2011) address selection into interracial marriages. They show that, on average, the matchings between white women and black men involve lower-"quality" partners using traditional metrics. White women who intermarry have a higher body mass index and lower education than other white women, while black men who intermarry are thinner and have lower wages than other black men. ${ }^{18}$ In our own data, we can further

${ }^{16}$ Because of this difference, we estimated the models below splitting the sample into two groups: mothers with a high school diploma or less and mothers with at least some college. The patterns documented below were nearly identical in the two sets of results, which are available on request. The fraction of black respondents completing high school in the Add Health data is very similar to the data from the 1997 National Longitudinal Study of Youth (NLSY), census, and Common Core. See Heckman and Lafontaine (2010) for a comparison.

17 Descriptive statistics pertaining to only boys showed patterns almost identical to those in table 3 .

${ }^{18}$ One area in which we observe a small disparity is intergenerational differences in grandparent inputs. That white women who marry black men have lower education suggests 
TABLE 3

Mean Father's Characteristics

\begin{tabular}{lccccc}
\hline & \multicolumn{5}{c}{ Group } \\
\cline { 2 - 6 } & $\begin{array}{c}\text { White } \\
\text { Students }\end{array}$ & $\begin{array}{c}\text { Black } \\
\text { Students }\end{array}$ & $\begin{array}{c}\text { Black with } \\
\text { White Mom }\end{array}$ & $\begin{array}{c}\text { Hispanic } \\
\text { Students }\end{array}$ & $\begin{array}{c}\text { Hispanic with } \\
\text { White Mom }\end{array}$ \\
\hline Know anything about? & .947 & $.848^{*}$ & .927 & $.874^{*}$ & $.875^{*}$ \\
& $(.004)$ & $(.012)$ & $(.038)$ & $(.015)$ & $(.027)$ \\
Currently live with? & {$[8,308]$} & {$[3,009]$} & {$[132]$} & {$[2,163]$} & {$[319]$} \\
& .651 & $.325^{*}$ & $.225^{*}$ & $.590^{*}$ & $.485^{\dagger}$ \\
Ever live with? & $(.010)$ & $(.022)$ & $(.056)$ & $(.031)$ & $(.043)$ \\
& {$[8,281]$} & {$[3,009]$} & {$[131]$} & {$[2,148]$} & {$[316]$} \\
Speak with weekly? & .921 & $.672^{*}$ & $.731^{*}$ & $.866^{*}$ & $.828^{*}$ \\
& $(.005)$ & $(.016)$ & $(.057)$ & $(.014)$ & $(.031)$ \\
Schooling & {$[8,233]$} & {$[2,961]$} & {$[130]$} & {$[2,117]$} & {$[313]$} \\
& .790 & $.560^{*}$ & $.384^{*}$ & .765 & $.683^{* \dagger}$ \\
Child support & $(.009)$ & $(.016)$ & $(.096)$ & $(.021)$ & $(.042)$ \\
& {$[7,485]$} & {$[2,413]$} & {$[110]$} & {$[1,848]$} & {$[256]$} \\
Interracial matching: & 13.6 & $13.0^{*}$ & 13.2 & $12.0^{*}$ & $13.2^{\dagger}$ \\
Female AHPVT & $(.1)$ & $(.1)$ & $(.5)$ & $(.2)$ & $(.3)$ \\
& {$[7,584]$} & {$[2,343]$} & {$[109]$} & {$[1,757]$} & {$[264]$} \\
& 126.63 & $58.90^{*}$ & $68.57^{*}$ & $48.41^{*}$ & 101.97 \\
Male AHPVT & $(5.57)$ & $(4.88)$ & $(23.15)$ & $(6.73)$ & $(29.17)$ \\
& {$[2,902]$} & {$[1,829]$} & {$[89]$} & {$[833]$} & {$[164]$} \\
& .080 & $-.572^{*}$ & $-.245^{* \dagger}$ & $-.486^{*}$ & $.060^{\dagger}$ \\
& {$[1,039)$} & $(.081)$ & $(.141)$ & $(.091)$ & $(.104)$ \\
& .298 & {$[826]$} & {$[81]$} & {$[417]$} & {$[96]$} \\
& $(.046)$ & $\left(.094^{*}\right.$ & $-.263^{*}$ & $-.500^{*}$ & $-.459^{*}$ \\
& {$[524]$} & {$[286]$} & $(.118)$ & $(.107)$ & $(.227)$ \\
& {$[444]$} & {$[251]$} & {$[59]$} \\
\hline
\end{tabular}

Note.-Standard errors for means are in parentheses; sample sizes are in brackets. All variables are measured at wave I. Child support is the monthly payment. The final two columns are drawn from the Add Health relationship histories gathered at wave III. The AHPVT test scores are drawn from a sample in which the unit of observation is a relationship which resulted in a pregnancy. Racial groups are defined from male and female races: white when both partners were white, black when the mother was black, and Hispanic when the mother was Hispanic. Interracial black and Hispanic groups are defined when the mother was white and the father black and Hispanic, respectively.

* Significantly different from the white student mean at the 5 percent level.

$\dagger$ Significantly different from the own minority group mean (black or Hispanic) at the 5 percent level.

investigate the role of selection into interracial couples by drawing on the wave III relationship histories within Add Health, which also allows us to learn about selection into interracial Hispanic couplings. We calculate the mean test score (a picture-vocabulary measure of recognition) within ownand cross-race relationships resulting in a pregnancy. ${ }^{19}$ The results are presented in the bottom two rows of table 3 . The highest test scores are found for white women with white men. White women who match with black men

that grandparent resources are negatively selected as well. Coresidence with grandparents is much higher among same-race black families than interracial families as well.

19 Note that this sample contains matches from the next generation, and selection into interracial relationships may have changed over time. 
have lower test scores than white women who match with white men but higher test scores than black women who match with black men. ${ }^{20}$ Similarly, black men who match with white women have lower test scores than white men who match with white women but higher test scores than black men who match with black women, though we cannot reject that this latter difference is zero. For Hispanic couplings, we see that white women matched with Hispanic men have the same average ability as other whites, but there are no differences between Hispanic men who match with white women and those who match with Hispanic women. Below, we show that with observable measures, we can explain virtually all the outcome gaps between both black and Hispanic children with white mothers, as well as their respective same-race counterparts. This suggests that selection in the marriage market is not driving our results or, at a minimum, that partner selection influences are mediated through other channels such as parenting and schools.

Next, we examine neighborhood and school characteristics across groups. Table 4 shows that black children with white mothers live in neighborhoods and attend schools with characteristics in between those of white students and other black students. This holds true for both racial diversity and the percentage of households below the poverty line. Looking at school-level characteristics reveals that the average AHPVT score at the schools that blacks with white mothers attend also lies between the corresponding score for white students and other black students. The same patterns hold for Hispanic children of white mothers, with the demographics of their neighborhoods and schools lying in between those of white students and other Hispanic students. Overall, the patterns suggest that differences in choice of neighborhood and school may be important in explaining differences in schooling and labor market outcomes.

\section{Descriptive Statistics: Outcomes}

We next examine outcome differences by the race of the student and the race of the mother, with the results reported in table 5. Observed wage and education gaps between blacks and whites are similar to those found in the literature and administrative data. Black wages in the Add Health are around 80 percent lower than white wages, as in Neal and Johnson (1996), and differences in college completion rates, 30 percent for whites versus 17 percent for blacks, are similar to the overall gap among whites and blacks in the US census in 2008 (30 percent for whites and 18 percent for blacks).

For differences by mother's race, white students and black students with white mothers have significantly higher test scores, math grades, and overall GPAs and, for male students, are more likely to have finished college and have higher wages. For all these measures, there is no significant dif-

20 This finding lines up with education ordering in Chiappori et al. (2011). 
TABLE 4

Mean Location Characteristics

\begin{tabular}{cccccc}
\hline & \multicolumn{5}{c}{ Group } \\
\cline { 2 - 6 } & $\begin{array}{c}\text { White } \\
\text { Students }\end{array}$ & $\begin{array}{c}\text { Black } \\
\text { Students }\end{array}$ & $\begin{array}{c}\text { Black with } \\
\text { White Mom }\end{array}$ & $\begin{array}{c}\text { Hispanic } \\
\text { Students }\end{array}$ & $\begin{array}{c}\text { Hispanic with } \\
\text { White Mom }\end{array}$ \\
\hline \% population white & .921 & $.371^{*}$ & $.739^{* \dagger}$ & $.664^{*}$ & $.835^{* \dagger}$ \\
& $(.008)$ & $(.029)$ & $(.035)$ & $(.032)$ & $(.021)$ \\
& {$[8,238]$} & {$[2,992]$} & {$[132]$} & {$[2,164]$} & {$[318]$} \\
\% population black & .048 & $.592^{*}$ & $.202^{*}$ & $.105^{*}$ & .065 \\
& $(.007)$ & $(.031)$ & $(.032)$ & $(.015)$ & $(.017)$ \\
& {$[8,238]$} & {$[2,992]$} & {$[132]$} & {$[2,164]$} & {$[318]$} \\
\% 1989 poverty & .108 & $.267^{*}$ & $.151^{\dagger}$ & $.200^{*}$ & $.126^{\dagger}$ \\
& $(.008)$ & $(.016)$ & $(.028)$ & $(.015)$ & $(.013)$ \\
School level: & {$[8,238]$} & {$[2,991]$} & {$[132]$} & {$[2,164]$} & {$[318]$} \\
$\%$ students black & .098 & $.550^{*}$ & $.264^{* \dagger}$ & $.169^{*}$ & .136 \\
& $(.013)$ & $(.048)$ & $(.054)$ & $(.022)$ & $(.024)$ \\
Average income & {$[8,044]$} & {$[2,981]$} & {$[131]$} & {$[2,101]$} & {$[308]$} \\
& 48.5 & $35.9 *$ & $43.0^{\dagger}$ & 36.9 & $45.9^{\dagger}$ \\
Average AHPVT & $(1.8)$ & $(2.2)$ & $(4.4)$ & $(2.2)$ & $(2.6)$ \\
& {$[7,445]$} & {$[2,558]$} & {$[120]$} & {$[1,786]$} & {$[285]$} \\
& .191 & $-.324^{*}$ & $.020^{\dagger}$ & $-.341^{*}$ & $-.020^{*}$ \\
& {$[.035)$} & $(.088)$ & $(.148)$ & $(.078)$ & $(.119)$ \\
& {$[7,987]$} & {$[2,876]$} & {$[127]$} & {$[2,085]$} & {$[306]$} \\
\hline
\end{tabular}

Note.-Standard errors for means in are parentheses; sample sizes are in brackets. All variables are measured at wave I. Block group means are from the 1990 census.

* Significantly different from the white student mean at the 5 percent level.

${ }^{\dagger}$ Significantly different from the own minority group mean (black or Hispanic) at the 5 percent level.

ference between white students and black students with white mothers. The only case in which black students with white mothers are more similar to black students than to white students is on grades in science classes. Hispanic students with white mothers also show significantly higher test scores than Hispanic students and have test scores that are not significantly different from those of white students. We view these differences as strong evidence against a genetic explanation: children from mixed-race couplings would have lower mean outcomes if they suffered from a genetic disadvantage. Given that white mothers of black children have low incomes and high rates of single parenthood, the notion that they could overcome a genetic disadvantage through increased child investment seems unrealistic. Hispanic students with white mothers have test scores and GPAs substantially higher than Hispanics as a whole, though they have slightly lower wages and employment levels.

Given work by Cascio and Staiger (2012) and Bond and Lang (2013) examining how test score scaling influences mean comparisons, we also plot the distribution of test scores for white students, black students, and black students with white mothers in figure 1 . The results are striking and reveal not only that there are similar means among children with white mothers but that both distributions stochastically dominate the distribu- 
TABLE 5

Mean Outcomes

\begin{tabular}{lccccc}
\hline & \multicolumn{5}{c}{ Group } \\
\cline { 2 - 6 } & $\begin{array}{c}\text { White } \\
\text { Students }\end{array}$ & $\begin{array}{c}\text { Black } \\
\text { Students }\end{array}$ & $\begin{array}{c}\text { Black with } \\
\text { White Mom }\end{array}$ & $\begin{array}{c}\text { Hispanic } \\
\text { Students }\end{array}$ & $\begin{array}{c}\text { Hispanic with } \\
\text { White Mom }\end{array}$ \\
\hline AHPVT Z-score & .310 & $-.540^{*}$ & $.105^{\dagger}$ & $-.617^{*}$ & $.138^{\dagger}$ \\
& $(.033)$ & $(.077)$ & $(.192)$ & $(.070)$ & $(.116)$ \\
Wave III: & {$[7,987]$} & {$[2,876]$} & {$[127]$} & {$[2,085]$} & {$[306]$} \\
Overall GPA & 2.72 & $2.13^{*}$ & $2.54^{\dagger}$ & $2.34^{*}$ & $2.54^{*}$ \\
& $(.01)$ & $(.07)$ & $(.12)$ & $(.04)$ & $.08)$ \\
Math GPA & {$[24,953]$} & {$[8,433]$} & {$[289]$} & {$[6,254]$} & {$[690]$} \\
& 2.36 & $1.77^{*}$ & $2.15^{\dagger}$ & $1.91^{*}$ & $2.18^{*}$ \\
Science GPA & $(.01)$ & $(.06)$ & $(.12)$ & $(.04)$ & $(.09)$ \\
& {$[21,455]$} & {$[7,662]$} & {$[260]$} & {$[5,434]$} & {$[590]$} \\
Wave IV: & 2.49 & $1.86^{*}$ & $2.15^{*}$ & $2.03^{*}$ & $2.26^{*}$ \\
Finished college & $(.02)$ & $(.07)$ & $(.16)$ & $(.06)$ & $(.09)$ \\
& {$[19,610]$} & {$[6,879]$} & {$[231]$} & {$[4,486]$} & {$[523]$} \\
Wages & & & & & \\
& .341 & $.219 *$ & .328 & $.193^{*}$ & $.247^{* \dagger}$ \\
Full-time employment & $(.020)$ & $(.029)$ & $(.070)$ & $(.018)$ & $(.050)$ \\
& {$[8,170]$} & {$[3,119]$} & {$[102]$} & {$[2,107]$} & {$[249]$} \\
& 18.31 & $15.20^{*}$ & 16.92 & 17.62 & 17.59 \\
& $(.327)$ & $(.543)$ & $(1.783)$ & $(.624)$ & $(1.101)$ \\
& {$[7,122]$} & {$[2,569]$} & {$[86]$} & {$[1,835]$} & {$[212]$} \\
& .909 & .886 & .870 & .900 & .801 \\
& $(.009)$ & $(.019)$ & $(.049)$ & $(.012)$ & $(.112)$ \\
& {$[8,170]$} & {$[3,121]$} & {$[102]$} & {$[2,108]$} & {$[250]$} \\
\hline
\end{tabular}

Note.-Standard errors for means are in parentheses; sample sizes are in brackets. AHPVT is measured at wave I, GPA is measured from transcripts at wave III, and completed education is measured at wave IV for males. The unit of observation for the GPA outcome is the individualyear; these standard errors are clustered at the individual level. Wages and full-time employment come from male respondents at wave IV.

* Significantly different from the white student mean at the 5 percent level.

$\dagger$ Significantly different from the own minority group mean (black or Hispanic) at the 5 percent level.

tion for black students. Thus using a scale-invariant measure, we observe similar patterns in the data. ${ }^{21}$

\section{Comparison to a Larger Sample}

Since the number of interracial children is small in Add Health, we compare our descriptives to another data set in which we observe the race of the mother, child, and a meaningful number of children from interracial couples. Namely, we examine vital statistics from the state of North Carolina. ${ }^{22}$ The means for background characteristics are presented in table 6 . On a number of measures, white mothers with black children look

${ }^{21}$ The distributions for whites, Hispanics, and Hispanics with white mothers look nearly identical to those plotted in fig. 1, with the white and Hispanic with white mother distributions overlapping and with both stochastically dominating the Hispanic distribution.

${ }^{22}$ These data are used with the permission of the North Carolina Education Research Data Center (NCERDC). 


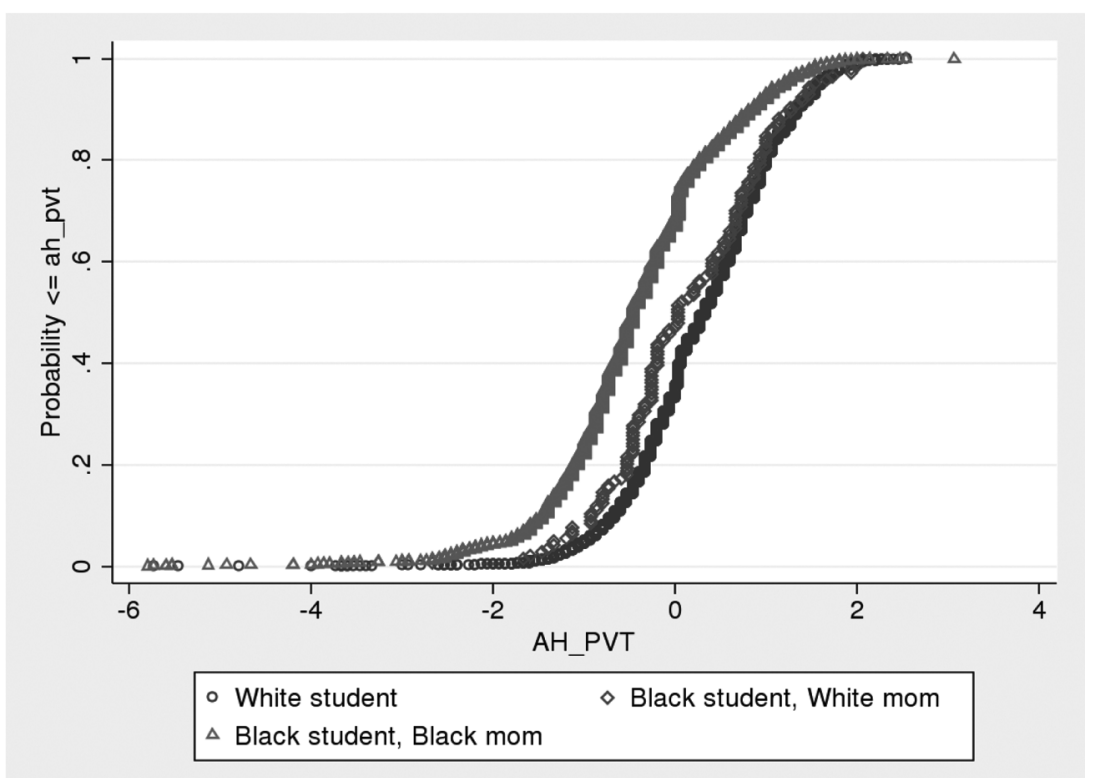

Figure 1.-PVT distributions. The figure plots the cumulative distribution function of both boys and girls among whites, blacks with a white mom, and blacks with a black mom.

similar to black mothers. The percentage receiving free or reduced lunch, our measure of economic need, is similar for both groups of black students and double the rate for white students. On outcomes such as mother's education, married at the time of birth, and maternal age, white mothers with black children are disadvantaged relative to black mothers. Just as in the Add Health data, Hispanic children with white mothers have higher income and more educated mothers and fathers than Hispanic students as a group, but they still have lower income and less educated parents compared to those of white families. Overall, the demographic patterns look similar for Add Health and administrative data from a large US state.

\section{Methods}

In a regression of the outcomes in table 5 against an intercept, a black indicator, and a Hispanic indicator, the coefficient on the intercept would replicate column 1 of table 5 and reflect the mean white outcomes; the coefficient on the black indicator would replicate the differences between mean white outcomes (col. 1) and black outcomes (col. 2); similarly, the coefficient on the Hispanic indicator would replicate the difference between column 1 and mean Hispanic outcomes in column 4.

Because there are small differences in the gender and age distribution of whites, blacks, and Hispanics in the sample, we estimate the regression above but also control for age in all specifications, as well as estimating the 
TABLE 6

Mean Background Characteristics in NCERDC Data

\begin{tabular}{lccccc}
\hline & \multicolumn{5}{c}{ Group } \\
\cline { 2 - 6 } & $\begin{array}{c}\text { White } \\
\text { Students }\end{array}$ & $\begin{array}{c}\text { Black } \\
\text { Students }\end{array}$ & $\begin{array}{c}\text { Black with } \\
\text { White Mom }\end{array}$ & $\begin{array}{c}\text { Hispanic } \\
\text { Students }\end{array}$ & $\begin{array}{c}\text { Hispanic with } \\
\text { White Mom }\end{array}$ \\
\hline Free/reduced lunch & .266 & $.728^{*}$ & $.639^{* \dagger}$ & $.702^{*}$ & $.571^{* \dagger}$ \\
& $(.001)$ & $(.001)$ & $(.006)$ & $(.004)$ & $(.008)$ \\
& {$[306,826]$} & {$[137,094]$} & {$[6,210]$} & {$[15,806]$} & {$[3,604]$} \\
Mother's education & 13.0 & $12.3^{*}$ & $11 . *^{*}$ & $9.6^{*}$ & $11.6^{* \dagger}$ \\
& $(.003)$ & $(.004)$ & $(.02)$ & $(.02)$ & $(.03)$ \\
Mother married at birth & {$[607,471]$} & {$[266,839]$} & {$[13,072]$} & {$[49,771]$} & {$[8,279]$} \\
& .860 & $.389^{*}$ & $.352^{* \dagger}$ & $.626^{*}$ & $.672^{* \dagger}$ \\
Mother's age at birth & $(.0004)$ & $(.001)$ & $(.004)$ & $(.002)$ & $(.005)$ \\
& {$[607,835]$} & {$[267,077]$} & {$[14,083]$} & {$[50,133]$} & {$[8,300]$} \\
Father's education & 26.9 & $24.7^{*}$ & $23.5^{* \dagger}$ & $25.0^{*}$ & $24.9^{*}$ \\
& $(.01)$ & $(.01)$ & $(.05)$ & $(.02)$ & $(.06)$ \\
& {$[607,719]$} & {$[267,035]$} & {$[14,083]$} & {$[50,131]$} & {$[8,302]$} \\
First birth & 13.0 & $12.5^{*}$ & $12.3^{* \dagger}$ & $9.5^{*}$ & $10.7^{* \dagger}$ \\
& $(.003)$ & $(.004)$ & $(.02)$ & $(.02)$ & $(.04)$ \\
& {$[577,430]$} & {$[184,505]$} & {$[11,440]$} & {$[45,441]$} & {$[7,750]$} \\
& .457 & $.399^{*}$ & $.476^{* \dagger}$ & $.389^{*}$ & $.389^{*}$ \\
& $(.001)$ & $(.001)$ & $(.004)$ & $(.002)$ & $(.002)$ \\
& {$[607,757]$} & {$[267,050]$} & {$[14,081]$} & {$[50,120]$} & {$[8,301]$} \\
\hline
\end{tabular}

Note.-Standard errors for means are in parentheses; sample sizes are in brackets. Means are all measured in third grade.

* Significantly different from the white student mean at the 5 percent level.

$\dagger$ Significantly different from the own minority group mean (black or Hispanic) at the 5 percent level.

regressions separately for boys and girls. Our baseline model that captures the difference in outcomes across groups is then

$$
Y_{i}=\alpha_{0}^{B}+\sum_{r} \alpha_{1 r}^{B} \times I\left(\text { Race }_{i}=r\right)+\alpha_{2}^{B} X_{i 1}+\varepsilon_{i}^{B},
$$

where the superscript $B$ denotes our baseline model. In a second regression, we then include a set of mother's characteristics, including maternal race, and father's characteristics. That is, we run

$$
Y_{i}=\alpha_{0}^{I}+\sum_{r} \alpha_{1 r}^{I} \times I\left(\text { Race }_{i}=r\right)+\alpha_{2}^{I} X_{i 1}+\alpha_{3}^{I} X_{i 2}+\alpha_{4}^{I} X_{i 3}+\varepsilon_{i}^{I},
$$

where the superscript $I$ denotes what we refer to as our intermediate model. In equation (2), mother's characteristics are denoted by $X_{i 2}$ and father's characteristics by $X_{i 3}$. Our main interest here is how much the additional factors in equation (2) help us explain the race effects found in equation (1). That is, $\alpha_{1 r}^{B}$ describes the difference in outcomes between groups not conditioning on paternal and maternal factors, and $\alpha_{1 r}^{I}$ does the same conditioning on those factors. Therefore, $\alpha_{1 r}^{B}-\alpha_{1 r}^{I}$ is the amount of the raw race effect accounted for by including the two variable sets.

It is of interest to assess the relative importance of maternal and paternal factors in explaining the racial outcome gaps and, where relevant, to distinguish if any specific factor in those groupings of factors is especially 
important. To implement this, we use a method developed by Gelbach (2009), which nests the well-known Oaxaca-Blinder decomposition. Gelbach points out that if equation (2) is the true model, equation (1) is just a model with the variable sets $X_{i 2}$ and $X_{i 3}$ omitted, implying that the wellknown omitted variable bias formula applies. That is, the relationship between $\alpha_{1 r}^{B}$ and $\alpha_{1 r}^{I}$ is simply

$$
\alpha_{1 r}^{B}=\alpha_{1 r}^{I}+\sum_{j=1}^{M} \delta_{3 j} \alpha_{3 j}^{I}+\sum_{j=1}^{P} \delta_{4 j} \alpha_{4 j}^{I},
$$

where $\alpha_{3 j}^{I}$ and $\alpha_{4 j}^{I}$ are defined in equation (2) and there are $M$ maternal characteristics and $P$ paternal characteristics. The $M \delta_{3}$ 's and $P \delta_{4}$ 's are defined by the auxiliary regression

$$
I\left(\text { Race }_{i}=r\right)=\delta_{0}+\delta_{2} X_{i 1}+\delta_{3} X_{i 2}+\delta_{4} X_{i 3}+\eta_{i} .
$$

A natural decomposition of how much each set of factors contribute to explaining the gap in outcomes is

$$
\alpha_{i r}^{B}-\alpha_{1 r}^{I}=\sum_{j=1}^{M} \delta_{3 j} \alpha_{3 j}^{I}+\sum_{j=1}^{P} \delta_{4 j} \alpha_{4 j}^{I} .
$$

The first term is the part of the gap explained by maternal factors. Also notice that one can evaluate the contribution of a single factor within each group. For example, if the first element of $X_{i 2}$ is maternal race, then $\delta_{31} \alpha_{31}^{I}$ is the contribution of maternal race in accounting for the initial gap in outcomes by child's race.

Since the descriptive statistics reveal differences in the schools and neighborhoods across student and mother pairs, we also include specifications with school fixed effects to see how school quality contributes to the racial gaps. Our final regression is then

$$
\begin{aligned}
Y_{i}= & \alpha_{0}^{F}+\sum_{r} \alpha_{1 r}^{F} \times I\left(\text { Race }_{i}=r\right)+\alpha_{2}^{F} X_{i 1}+\alpha_{3}^{F} X_{i 2}+\alpha_{4}^{F} X_{i 3} \\
& +\sum_{j}^{J} \alpha_{5 j}^{F} I\left(\operatorname{School}_{i}=j\right)+\varepsilon_{i}^{F} .
\end{aligned}
$$

We can decompose the difference from equation (1) into

$$
\alpha_{1 r}^{B}-\alpha_{1 r}^{F}=\sum_{j=1}^{M} \theta_{3 j} \alpha_{3 j}^{F}+\sum_{j=1}^{P} \theta_{4 j}^{F} \alpha_{4 j}^{F}+\sum_{j=1}^{J} \theta_{5 j} \alpha_{5 j}^{F},
$$

where the $\theta$ 's are from an extended auxiliary regression that adds school fixed effects to equation (4) and uses $\theta$ for coefficients rather than $\delta$. Now if we compare the contributions from maternal characteristics in equation (5) to those in equation (7), we see how much of the racial gap is still attributed to characteristics of the mother. If the attribution is reduced substantially by including school fixed effects, then one would conclude that the choice of school is an important mechanism through which characteristics of the mother operate. 


\section{Results}

Regression results in which the outcome measures are PVT (test scores), math grades, and log wages are presented in table 7 . Test scores are standardized so that coefficients are interpreted as fractions of a standard deviation. Observations for math grades are at the course-year level and are on a four-point scale. ${ }^{23} \mathrm{Log}$ wages are taken from the data in wave IV and are conditional on working. ${ }^{24}$ All the results reported in table 7 use sampling weights. Unweighted results as well as results using different outcome measures are given in the Appendix. ${ }^{25}$

Panel A of table 7 gives the results for boys. The first three columns show racial gaps when we just control for age of the child. To illustrate how quickly own-race effects disappear, the second set shows results in which we just condition on characteristics of the mother. The final two sets of columns show the results that are then used in the decomposition analysis, adding characteristics of the father and then additionally adding school fixed effects. The first column shows baseline test score gaps relative to whites of over 0.8 standard deviations for both black and Hispanic students. Adding characteristics of the mother alone reduces the effects of own race to be small and insignificant. Large gaps are present, however, when comparing children of white mothers with children of black and Hispanic mothers, with children of black (Hispanic) mothers scoring 0.74 (0.51) standard deviations worse than children of white mothers. Only small drops in the estimates occur when father's characteristics are also added. Adding school fixed effects reduces the estimated gap between children of black mothers and white mothers to 0.42 standard deviations, suggesting that choice of schools is part of the reason for differences across these two groups.

For math grades and wages, similar patterns emerge for black males. Namely, large initial gaps exist between black and white students that disappear once we account for background characteristics, particularly mother's race. Children of black mothers have math grades that are almost half a point lower than those of children of white mothers, with the gap falling to 0.4 points once we add school fixed effects. ${ }^{26}$ For wages, children of black mothers earn 20 percent lower wages than children of white mothers regardless of whether characteristics of the father or school fixed effects

23 The course-specific GPA data come from each year in which an individual took a math course in school as recorded in the wave III transcript file. The math GPA baseline regressions include an interaction between the level of math course (e.g., algebra or geometry) and the year of school in which it was taken (e.g., as a sophomore or junior). The standard errors for all GPA regressions are clustered at the individual level.

${ }^{24}$ We focus on wave IV since the average age in this wave was around 28 , beyond the period when most schooling is completed.

25 The additional outcome measures we consider are science GPA, overall GPA, and whether the student obtained a 4-year degree by wave IV.

${ }^{26}$ Given concerns about differential promotion and GPA scaling, we estimated an ordered probit of highest math level completed in school and found significant differences between black and white students as well as significant differences between black and white mothers, though these effects are very noisy and insignificant once we control for school fixed effects. 


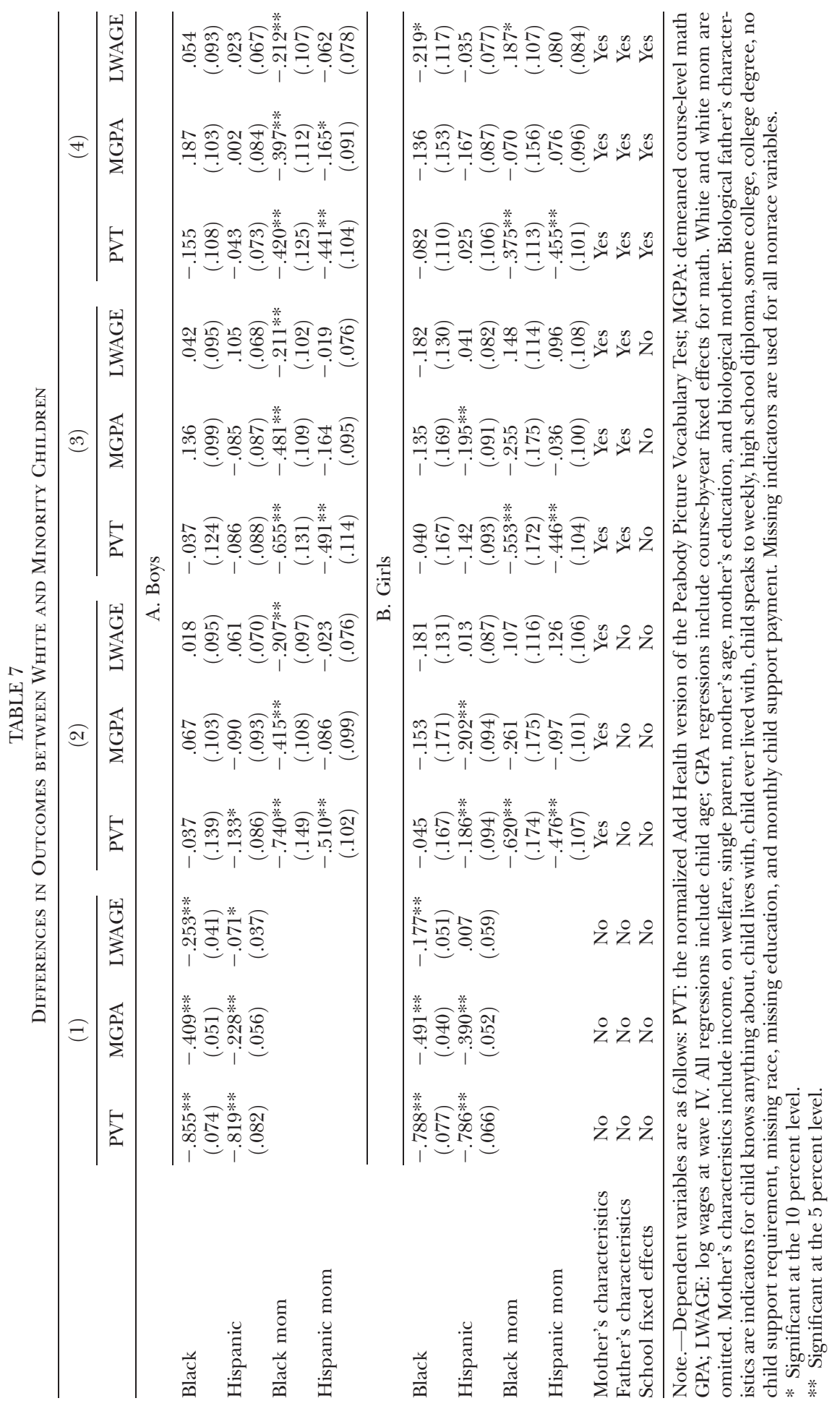


are included. ${ }^{27}$ For Hispanics, the estimates are less precise but the same patterns emerge: virtually no effect of own race and negative estimates for children of Hispanic mothers relative to white mothers.

Panel B of table 7 shows results for girls. For test scores, we see the same patterns as for boys, namely, large negative effects of own race that are small and insignificant once we control for family background characteristics. We again see that children of black and Hispanic mothers have significantly lower test scores with the effects attenuated for blacks once we control for school fixed effects. The picture is more muddled for math GPA and $\log$ wages, actually showing positive and significant effects for children of black mothers in the labor market once we account for school fixed effects. However, this latter result should be interpreted with caution given that selection into the labor market is a much bigger concern for females.

\section{A. Decomposition}

Given the large fraction of the raw gaps that can be explained with observables, we turn to decomposing the changes among the various sets of controls using equation (5). We report results for decompositions both with and without school fixed effects for each of the three outcome measures in tables 8 and 9 for boys and girls, respectively. Three numbers are reported in each cell. First is the amount of the gap explained by the particular set of characteristics, with asterisks denoting the significance of the joint test that the variables in the group explain variation in the outcome equation. Second, the number in parentheses is the standard error of this estimate. Finally, the number in brackets is the fraction of the raw gap that is accounted for by this set, which is the variable group coefficient divided by the raw gap. The bottom row in each panel then shows the total explained gap as well as the baseline gap.

The first column for boys in table 8 shows that without school fixed effects, maternal race accounts for over 71 percent of the black and 55 percent of the Hispanic PVT score gap observed during adolescence. Including school fixed effects (moving from col. 1 to col. 4) drops this fraction to 46 percent for both blacks and Hispanics, suggesting that school quality plays a much larger role for children of black mothers. ${ }^{28}$ Other maternal characteristics are also important, accounting for 12.4 percent and 8.5 percent of the raw gap for blacks without and with school fixed effects, respectively. The corresponding numbers for Hispanics are larger at 27.5 percent and 19.9 percent. Characteristics of the father are less important and are actually insignificant for blacks once school fixed effects are included.

\footnotetext{
${ }^{27}$ Focusing instead on earnings (where the sample is then all those who have positive earnings) yielded identical findings.

28 Given the importance of school quality, one may be concerned that the effects of school quality are heterogeneous depending on student race. Specifications including school fixed effects interacted with race showed no significant changes in the maternal race coefficients, and in the case of blacks, we could reject their inclusion. Results are available on request.
} 
TABLE 8

Decomposing Minority Outcome Gaps among Boys

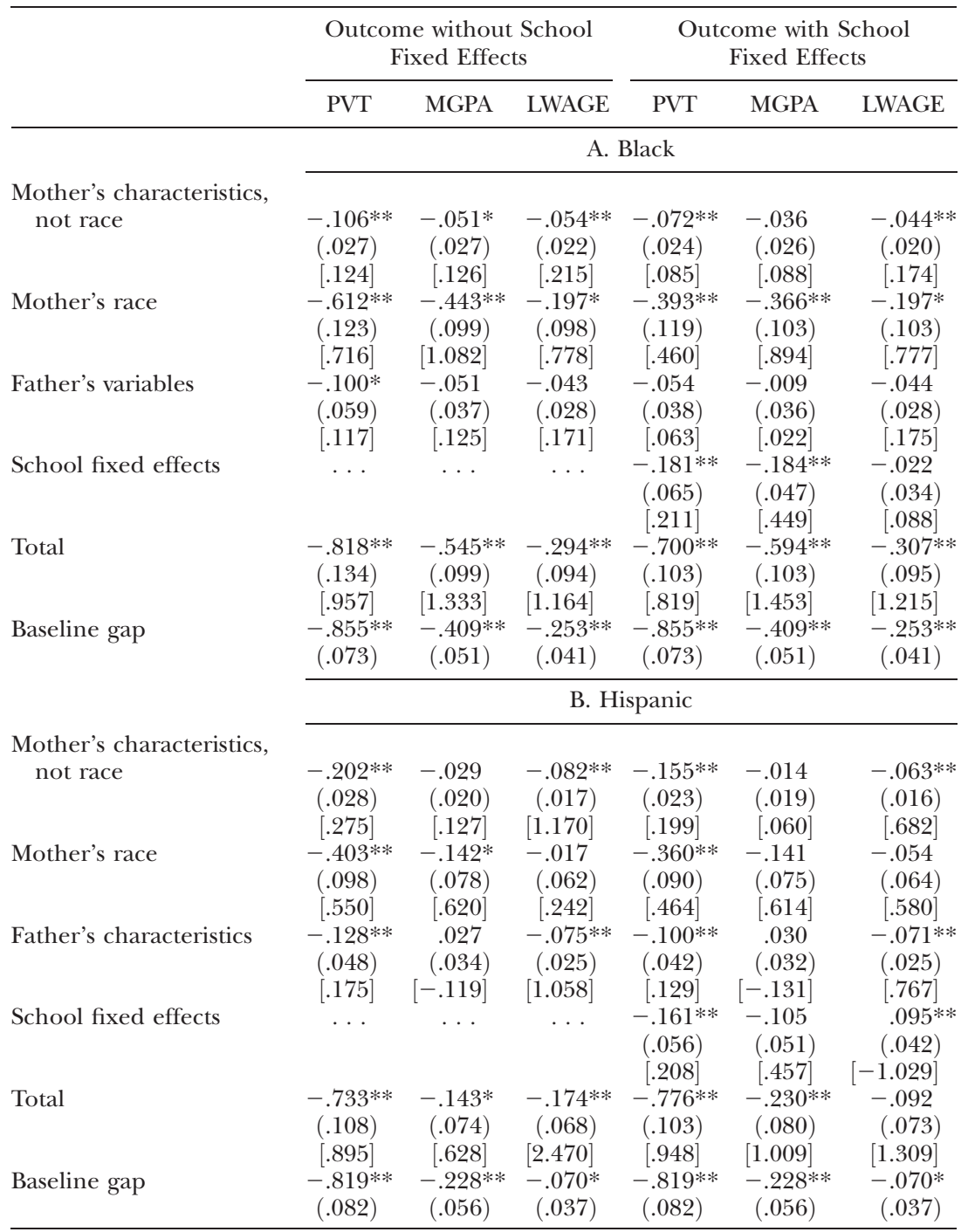

Note.-Each cell contains the effect of each variable group on the white minority outcome gap. The standard errors are in parentheses, and the fraction of the baseline outcome gap explained is in brackets. Dependent variables are the normalized Add Health version of the Peabody Picture Vocabulary Test, demeaned course-level GPA, and log wages at wave IV. All regressions include child age, and GPA regressions include course-by-year fixed effects for math. White and white mom are omitted. Characteristics are listed in the note to table 7.

* Significant at the 10 percent level.

** Significant at the 5 percent level. 
TABLE 9

Decomposing Minority Outcome Gaps among Girls

\begin{tabular}{|c|c|c|c|c|}
\hline & \multicolumn{2}{|c|}{$\begin{array}{l}\text { Outcome without } \\
\text { School Fixed Effects }\end{array}$} & \multicolumn{2}{|c|}{$\begin{array}{c}\text { Outcome with School } \\
\text { Fixed Effects }\end{array}$} \\
\hline & PVT & MGPA & PVT & MGPA \\
\hline & \multicolumn{4}{|c|}{ A. Black } \\
\hline Mother's characteristics, not race & $\begin{array}{c}.089 * * \\
(.030) \\
{[.113]}\end{array}$ & $\begin{array}{r}-.028 \\
(.023) \\
.057]\end{array}$ & $\begin{array}{c}-.056 * * \\
(.023) \\
{[.071]}\end{array}$ & $\begin{array}{r}-.021 \\
(.022) \\
.043]\end{array}$ \\
\hline Mother's race & $\begin{array}{c}-.530 * * \\
(.166) \\
{[.673]}\end{array}$ & $\begin{array}{r}-.244 \\
(.168) \\
{[.498]}\end{array}$ & $\begin{array}{c}-.358^{* *} \\
(.110) \\
{[.455]}\end{array}$ & $\begin{array}{r}-.067 \\
(.150) \\
{[.136]}\end{array}$ \\
\hline Father's characteristics & $\begin{array}{c}-.131^{*} \\
(.046) \\
.166]\end{array}$ & $\begin{array}{c}-.084 * * \\
(.029) \\
{[.171]}\end{array}$ & $\begin{array}{c}-.091 * * \\
(.038) \\
.116]\end{array}$ & $\begin{array}{c}-.076 * * \\
(.028) \\
.154]\end{array}$ \\
\hline School fixed effects & $\ldots$ & $\ldots$ & $\begin{array}{c}-.200^{* *} \\
(.075) \\
.254]\end{array}$ & $\begin{array}{c}-.191 * * \\
(.039) \\
.389]\end{array}$ \\
\hline Total & $\begin{array}{c}-.749 * * \\
(.178) \\
{[.952]}\end{array}$ & $\begin{array}{c}-.356 * * \\
(.165) \\
{[.725]}\end{array}$ & $\begin{array}{c}-.705^{* *} \\
(.135) \\
{[.896]}\end{array}$ & $\begin{array}{c}-.355 * * \\
(.151) \\
{[.722]}\end{array}$ \\
\hline \multirow[t]{2}{*}{ Baseline gap } & $\begin{array}{l}-.788^{* * *} \\
(.076)\end{array}$ & $\begin{array}{l}-.491 * * \\
(.040)\end{array}$ & $\begin{array}{l}-.788^{* *} \\
(.076)\end{array}$ & $\begin{array}{c}-.491^{* * *} \\
(.040)\end{array}$ \\
\hline & \multicolumn{4}{|c|}{ B. Hispanic } \\
\hline Mother's characteristics, not race & $\begin{array}{c}-.151 * * \\
(.025) \\
{[.184]}\end{array}$ & $\begin{array}{c}-.059 * * \\
(.018) \\
{[.153]}\end{array}$ & $\begin{array}{c}-.122 * * \\
(.023) \\
{[.149]}\end{array}$ & $\begin{array}{c}-.056 * * \\
(.018) \\
{[.143]}\end{array}$ \\
\hline Mother's race & $\begin{array}{c}-.358^{* *} \\
(.086) \\
.438]\end{array}$ & $\begin{array}{c}-.044 \\
(.078) \\
{[.114]}\end{array}$ & $\begin{array}{c}-.365^{* *} \\
(.083) \\
.445]\end{array}$ & $\begin{array}{r}.063 \\
(.080) \\
-.162]\end{array}$ \\
\hline Father's characteristics & $\begin{array}{c}-.133^{* *} \\
(.029) \\
{[.163]}\end{array}$ & $\begin{array}{c}-.096 * * \\
(.025) \\
{[.247]}\end{array}$ & $\begin{array}{c}-.083^{* *} \\
(.030) \\
{[.101]}\end{array}$ & $\begin{array}{c}-.085^{* *} \\
(.024) \\
{[.218]}\end{array}$ \\
\hline School fixed effects & $\ldots$ & $\ldots$ & $\begin{array}{c}-.241 * * \\
(.093) \\
{[.295]}\end{array}$ & $\begin{array}{c}-.145 * * \\
(.043) \\
{[.373]}\end{array}$ \\
\hline Total & $\begin{array}{c}-.643^{* *} \\
(.097) \\
.785\end{array}$ & $\begin{array}{c}-.643^{* *} \\
(.097) \\
{[1.648]}\end{array}$ & $\begin{array}{c}-.810 \\
(.129) \\
.990]\end{array}$ & $\begin{array}{c}-.223 * * \\
(.083) \\
.571]\end{array}$ \\
\hline Baseline gap & $\begin{array}{l}-.819 * * \\
(.082)\end{array}$ & $\begin{array}{l}-.390 * * \\
(.052)\end{array}$ & $-.819 * *$ & $\begin{array}{l}-.390 * * \\
(.052)\end{array}$ \\
\hline
\end{tabular}

Note.-Each cell contains the effect of each variable group on the white minority outcome gap. The standard error is in parentheses, and the fraction of the baseline gap explained is in brackets. Dependent variables are the normalized Add Health version of the Peabody Picture Vocabulary Test and demeaned course-level GPA. All regressions include child age, and GPA regressions include course-by-year fixed effects for math. White and white mom are omitted. Characteristics are listed in the note to table 7.

* Significant at the 10 percent level.

** Significant at the 5 percent level. 
Race of the mother is an even more important factor in accounting for gaps in math grades and log wages for black males, explaining over 77 percent of the raw gap regardless of whether school fixed effects are included. For Hispanic males, we see large effects of mother's race for math grades, which explain over 60 percent of the Hispanic-white gap, but the effects for wages are noisy. The latter is understandable given that the base difference in log wages was small.

We perform the same exercise for girls in table $9 .{ }^{29}$ As with males, race of the mother is the dominant factor in explaining racial test score gaps. Mother's race accounts for 67 percent and 45 percent of the black-white gap without and with school fixed effects, respectively, again suggesting that school quality is one of the mechanisms through which the race of the mother operates. Having a Hispanic mother is also the dominant factor for the Hispanic-white test score gap, accounting for around 44 percent of the raw gap, regardless of controls for school fixed effects. However, we see no significant effects of mother's race for math grades.

\section{B. Channels}

Given the dominant factor that race of the mother plays in accounting for racial gaps in school and in the labor market, particularly for black and Hispanic boys, we next seek to understand whether parenting practices differ depending on the race of the mother and whether these differences can begin to account for the larger mother race effects. Variables related to characteristics of the child's birth, behaviors of the mother, and how the parent and child interact are summarized in table 10.

A number of differences across family types emerge. White mothers raising black children are less likely to agree that the mother fosters child independence but also encourages more participation in hobbies (e.g., reading, arts, and music). ${ }^{30}$ These mothers are also more likely to discuss behavior problems than mothers of blacks or whites. Black children raised by white mothers have higher birth weights and lower rates of breastfeeding than black children raised by black mothers. Differences in time use are also present, with white mothers of black children more likely to work, working more hours, and correspondingly spending less time at home before and after school. Black children raised by white mothers also watch significantly less television than other black children but more television than white children.

${ }^{29}$ We do not report decomposition results for female wages as the controls had no significant effects on racial wage gaps for this group.

30 Many authors have exploited the emotional support and cognitive stimulation HOME scores from the NLSY 1979 to explain cognitive production and achievement (see, e.g., Carneiro, Heckman, and Masterov 2005; Cunha et al. 2006; Todd and Wolpin 2007). Since a number of the questions overlap between these indices and the Add Health survey instrument, we examine the variables that overlap: the frequency of engaging in hobbies, arts, or playing music; whether the mother encourages independence; and whether the child is involved in no extracurricular activities. These form our set of Add Health HOME score variables. 
TABLE 10

Differences in Parenting Behaviors across Families

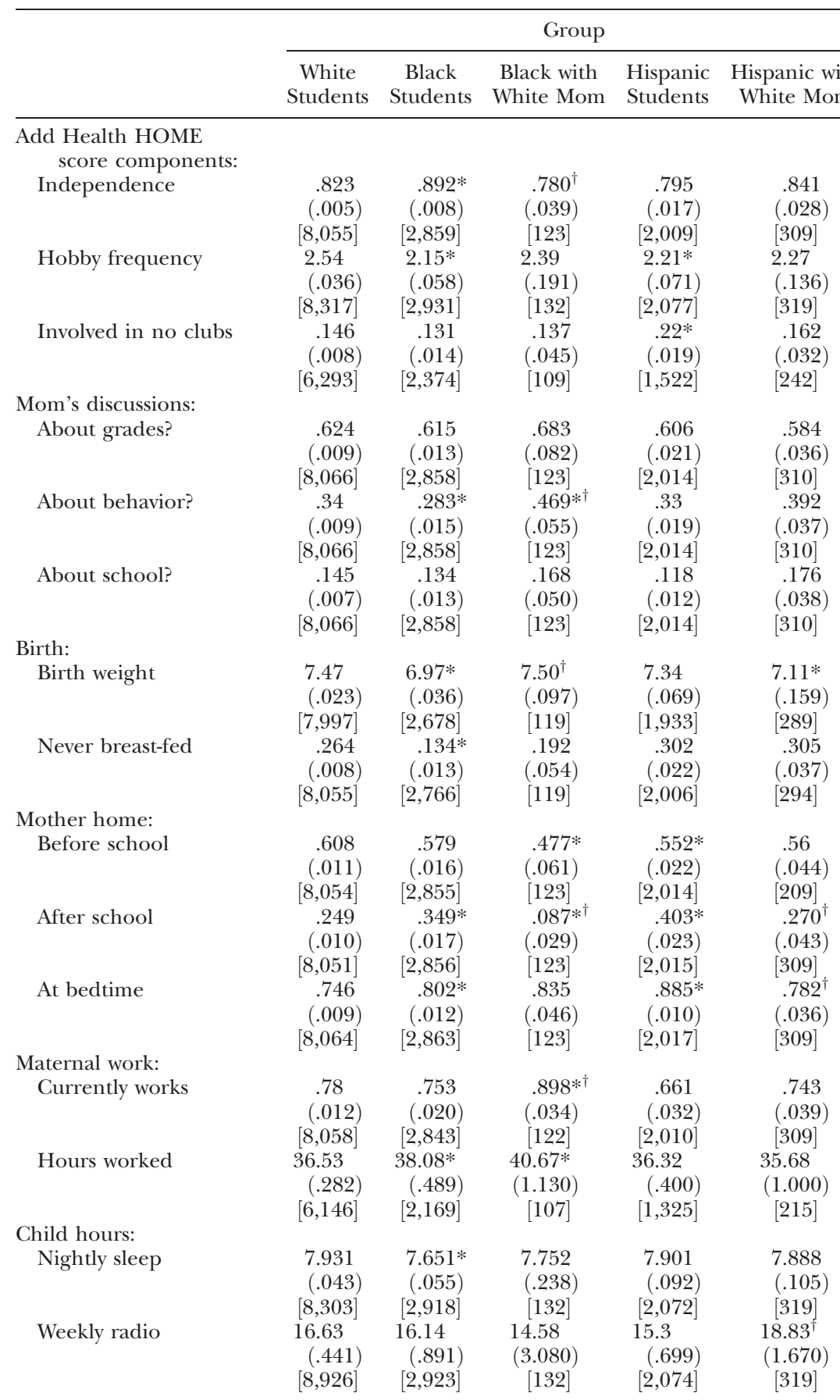


TABLE 10 (Continued)

\begin{tabular}{lccccc}
\hline & \multicolumn{5}{c}{ Group } \\
\cline { 2 - 6 } & $\begin{array}{c}\text { White } \\
\text { Students }\end{array}$ & $\begin{array}{c}\text { Black } \\
\text { Students }\end{array}$ & $\begin{array}{c}\text { Black with } \\
\text { White Mom }\end{array}$ & $\begin{array}{c}\text { Hispanic } \\
\text { Students }\end{array}$ & $\begin{array}{c}\text { Hispanic with } \\
\text { White Mom }\end{array}$ \\
\hline Weekly TV & 14.2 & $20.44^{*}$ & $17.30^{* \dagger}$ & $16.74^{*}$ & 15.66 \\
& $(.355)$ & $(.782)$ & $(1.306)$ & $(.548)$ & $(1.429)$ \\
Weekly video/computer & {$[8,298]$} & {$[2,914]$} & {$[132]$} & {$[2,072]$} & {$[318]$} \\
games & 2.666 & $3.56^{*}$ & 3.456 & 2.713 & 2.863 \\
& $(.121)$ & $(.265)$ & $(.668)$ & $(.229)$ & $(.702)$ \\
Hobbies & {$[8,311]$} & {$[2,927]$} & {$[132]$} & {$[2,077]$} & {$[319]$} \\
& 1.543 & $1.306^{*}$ & 1.443 & $1.347^{*}$ & $1.383^{*}$ \\
& -.022 & -.034 & -.11 & -.042 & -.079 \\
& {$[8,317]$} & {$[2,930]$} & {$[132]$} & {$[2,077]$} & {$[319]$} \\
\hline
\end{tabular}

Note.-Standard errors for means are in parentheses; sample sizes are in brackets. Means are all measured at wave I. Add Health HOME questions are similar to NLSY79 HOME score questions: independence is whether the mother encourages independence, agree or stronly agree; hobby frequency includes music, art, and reading; 1 corresponds to 1 or 2 times, 2 to 3 or 4 times, and 3 to 5 or more times. Discussion questions are from the prior 4 weeks.

* Significantly different from the white student mean at the 5 percent level.

† Significantly different from the own minority group mean (black or Hispanic) at the 5 percent level.

In table 11, we add this large set of controls to equation (6) and present the accompanying decomposition for boys. ${ }^{31}$ Despite the differences seen in table 10, the importance of maternal race is unchanged. ${ }^{32}$ Different sets of the additional variables have significant effects on the gaps depending on the outcome, but the effects are small. For example, birth mechanisms (birth weight and breast-feeding) influence both PVT and wages for blacks, but their effect is about one-tenth of the size of the effect of mother's race. For Hispanics, the additional controls have even less explanatory power.

\section{Robustness Checks}

There are at least four issues with the analysis conducted in the previous section. The first is selection into interracial relationships. On the basis of observables, as shown in Section III, white mothers with black children appear to be negatively selected compared to other white mothers, yet their children have outcomes similar to those of white children given our controls. On observables, white mothers with black children look very similar to black mothers, yet the outcomes for their children are very different. These two patterns suggest that selection is an unlikely explanation for our results.

${ }^{31}$ Following the discussion in Fryer and Levitt (2004), we also experimented with many school quality measures, none of which had significant impacts on the coefficients for most outcomes. This result is consistent with that in Fryer and Levitt (2013).

${ }^{32}$ Similar results are found for girls' PVT scores: maternal race is still the single-most important factor (explaining roughly 50 percent of the outcome gap) even after conditioning on the large vector of controls. 
TABLE 11

Decomposing Minority Outcome Gaps among Boys Using More Channels

\begin{tabular}{|c|c|c|c|c|c|c|}
\hline & \multicolumn{3}{|c|}{$\begin{array}{l}\text { Outcome without School } \\
\text { Fixed Effects }\end{array}$} & \multicolumn{3}{|c|}{$\begin{array}{l}\text { Outcome with School } \\
\text { Fixed Effects }\end{array}$} \\
\hline & PVT & MGPA & LWAGE & PVT & MGPA & LWAGE \\
\hline & \multicolumn{6}{|c|}{ A. Blacks } \\
\hline $\begin{array}{l}\text { Mother's characteristics, } \\
\text { not race }\end{array}$ & $\begin{array}{c}-.102 * * \\
(.030) \\
{[.119]}\end{array}$ & $\begin{array}{l}-.020 \\
(.028) \\
{[.048]}\end{array}$ & $\begin{array}{c}-.027 \\
(.022) \\
{[.106]}\end{array}$ & $\begin{array}{c}-.067 * * \\
(.024) \\
{[.079]}\end{array}$ & $\begin{array}{r}-.006 \\
(.027) \\
{[.016]}\end{array}$ & $\begin{array}{c}-.022 \\
(.022) \\
{[.085]}\end{array}$ \\
\hline Mother's race & $\begin{array}{c}-.570^{* * *} \\
(.121) \\
{[.667]}\end{array}$ & $\begin{array}{r}-.436 \\
(.104) \\
{[1.065]}\end{array}$ & $\begin{array}{c}-.174 * \\
(.102) \\
{[.686]}\end{array}$ & $\begin{array}{c}-.385^{* *} \\
(.116) \\
{[.450]}\end{array}$ & $\begin{array}{c}-.375^{* *} \\
(.106) \\
{[.917]}\end{array}$ & $\begin{array}{c}-.175^{*} \\
(.107) \\
{[.693]}\end{array}$ \\
\hline Father's characteristics & $\begin{array}{c}-.051 \\
(.041) \\
{[.060]}\end{array}$ & $\begin{array}{c}-.015 \\
(.039) \\
{[.038]}\end{array}$ & $\begin{array}{c}-.024 \\
(.027) \\
{[.096]}\end{array}$ & $\begin{array}{c}-.029 \\
(.037) \\
{[.034]}\end{array}$ & $\begin{array}{c}.028 \\
(.038) \\
{[-.069]}\end{array}$ & $\begin{array}{c}-.033 \\
(.027) \\
{[.130]}\end{array}$ \\
\hline $\begin{array}{l}\text { Add Health HOME } \\
\text { score }\end{array}$ & $\begin{array}{r}-.002 \\
(.009) \\
{[.009]}\end{array}$ & $\begin{array}{r}.007 \\
(.011) \\
-018]\end{array}$ & $\begin{array}{r}.005 \\
(.004) \\
--021]\end{array}$ & $\begin{array}{r}-.005 \\
(.010) \\
{[.006]}\end{array}$ & $\begin{array}{c}.011 \\
(.010) \\
--027]\end{array}$ & $\begin{array}{r}.006 \\
(.005) \\
{[-029]}\end{array}$ \\
\hline Time use - mom & $\begin{array}{c}{[.002]} \\
-.024 \\
(.015) \\
{[.029]}\end{array}$ & $\begin{array}{c}.008 \\
(.015) \\
{[-.020]}\end{array}$ & $\begin{array}{c}{\left[.013^{*}\right.} \\
(.007) \\
.0511\end{array}$ & $\begin{array}{c}{[.000]} \\
-.024 * * \\
(.011) \\
.028]\end{array}$ & $\begin{array}{l}.000 \\
(.011) \\
.000]\end{array}$ & $\begin{array}{c}{[-.011]} \\
-.011 \\
(.008) \\
.043]\end{array}$ \\
\hline Time use-child & $\begin{array}{c}-.020 \\
(.018) \\
{[.023]}\end{array}$ & $\begin{array}{c}-.021 \\
(.009) \\
.051]\end{array}$ & $\begin{array}{c}-.016 \\
(.011) \\
.0631\end{array}$ & $\begin{array}{c}-.007 \\
(.009) \\
.008\end{array}$ & $\begin{array}{c}-.014 * \\
(.009) \\
{[.034]}\end{array}$ & $\begin{array}{c}-.025 \\
(.023) \\
{[.098]}\end{array}$ \\
\hline Birth mechanisms & $\begin{array}{c}-.047 * * \\
(.010) \\
{[.055]}\end{array}$ & $\begin{array}{c}-.013 \\
(.011) \\
.031]\end{array}$ & $\begin{array}{c}-.018^{*} \\
(.009) \\
.070]\end{array}$ & $\begin{array}{c}-.042 * * \\
(.010) \\
{[.049]}\end{array}$ & $\begin{array}{c}-.007 \\
(.011) \\
.017]\end{array}$ & $\begin{array}{c}-.015 \\
(.010) \\
.058\end{array}$ \\
\hline Parenting discussions & $\begin{array}{c}-.001 \\
(.023) \\
{[.001]}\end{array}$ & $\begin{array}{c}-.042 \\
(.027) \\
{[.104]}\end{array}$ & $\begin{array}{r}-.016 \\
(.016) \\
{[.064]}\end{array}$ & $\begin{array}{c}-.003 \\
(.019) \\
{[.003]}\end{array}$ & $\begin{array}{c}-.049 * * \\
(.025) \\
{[.120]}\end{array}$ & $\begin{array}{c}-.018 \\
(.016) \\
{[.071]}\end{array}$ \\
\hline School fixed effects & $\ldots$ & $\ldots$ & $\ldots$ & $\begin{array}{c}-.160^{* * *} \\
(.056) \\
{[.187]}\end{array}$ & $\begin{array}{c}-.166^{* *} \\
(.048) \\
{[.405]}\end{array}$ & $\begin{array}{c}.009 \\
(.037) \\
{[-.037]}\end{array}$ \\
\hline \multirow[t]{3}{*}{ Total } & $\begin{array}{c}-.816^{* *} \\
(.130) \\
{[.955]}\end{array}$ & $\begin{array}{c}-.531^{* *} \\
(.104) \\
{[1.298]}\end{array}$ & $\begin{array}{c}-.283 * * \\
(.098) \\
{[1.116]}\end{array}$ & $\begin{array}{c}-.721 * * \\
(.105) \\
{[.843]}\end{array}$ & $\begin{array}{c}-.579 * * \\
(.106) \\
{[1.414]}\end{array}$ & $\begin{array}{c}-.283^{* *} \\
(.099) \\
{[1.118]}\end{array}$ \\
\hline & $\begin{array}{c}-.855^{* * *} \\
(.073) \\
\end{array}$ & $\begin{array}{c}-.409 * * \\
(.051)\end{array}$ & $\begin{array}{c}-.253^{* * *} \\
(.041)\end{array}$ & $\begin{array}{c}-.855^{* *} \\
(.073)\end{array}$ & $\begin{array}{c}-.409 * * \\
(.051)\end{array}$ & $\begin{array}{c}-.253 * * \\
(.041) \\
\end{array}$ \\
\hline & \multicolumn{6}{|c|}{ B. Hispanics } \\
\hline $\begin{array}{l}\text { Mother's characteristics, } \\
\text { not race }\end{array}$ & $\begin{array}{c}-.187 * * \\
(.029) \\
{[.228]}\end{array}$ & $\begin{array}{c}-.020 \\
(.028) \\
.086]\end{array}$ & $\begin{array}{c}-.067 * * \\
(.018) \\
{[.953]}\end{array}$ & $\begin{array}{c}-.147 * * \\
(.023) \\
{[.179]}\end{array}$ & $\begin{array}{r}-.016 \\
(.019) \\
.068]\end{array}$ & $\begin{array}{c}-.052 * * \\
(.017) \\
{[.743]}\end{array}$ \\
\hline Mother's race & $\begin{array}{c}-.386^{* *} \\
(.096) \\
{[.471]}\end{array}$ & $\begin{array}{r}-.436 \\
(.104) \\
{[1.909]}\end{array}$ & $\begin{array}{c}.005 \\
(.062) \\
{[-.068]}\end{array}$ & $\begin{array}{c}-.353 * * \\
(.088) \\
{[.431]}\end{array}$ & $\begin{array}{c}-.129 * \\
(.078) \\
.567]\end{array}$ & $\begin{array}{c}-.042 \\
(.065) \\
.591]\end{array}$ \\
\hline Father's characteristics & $\begin{array}{c}-.071 * * \\
(.033) \\
{[.087]}\end{array}$ & $\begin{array}{c}-.015 \\
(.039) \\
{[.068]}\end{array}$ & $\begin{array}{c}-.042^{* *} \\
(.020) \\
{[.591]}\end{array}$ & $\begin{array}{c}-.062^{*} \\
(.037) \\
{[.076]}\end{array}$ & $\begin{array}{c}.052 \\
(.030) \\
{[-.229]}\end{array}$ & $\begin{array}{r}-.040^{*} \\
(.022) \\
{[.567]}\end{array}$ \\
\hline $\begin{array}{l}\text { Add Health HOME } \\
\text { score }\end{array}$ & $\begin{array}{c}-.017 \\
(.018) \\
{[.020]}\end{array}$ & $\begin{array}{c}.007 \\
(.011) \\
{[-.032]}\end{array}$ & $\begin{array}{l}-.011 \\
(.009) \\
{[.155]}\end{array}$ & $\begin{array}{c}-.030 * \\
(.019) \\
{[.037]}\end{array}$ & $\begin{array}{c}-.018^{*} \\
(.011) \\
.077]\end{array}$ & $\begin{array}{c}-.014 \\
(.010) \\
{[.199]}\end{array}$ \\
\hline
\end{tabular}


TABLE 11 (Continued)

\begin{tabular}{|c|c|c|c|c|c|c|}
\hline & \multicolumn{3}{|c|}{$\begin{array}{c}\text { Outcome without School } \\
\text { Fixed Effects }\end{array}$} & \multicolumn{3}{|c|}{$\begin{array}{l}\text { Outcome with School } \\
\text { Fixed Effects }\end{array}$} \\
\hline & PVT & MGPA & LWAGE & PVT & MGPA & LWAGE \\
\hline Time use-mom & $\begin{array}{r}-.008 \\
(.026) \\
{[.009]}\end{array}$ & $\begin{array}{c}.008 \\
(.015) \\
{[-.037]}\end{array}$ & $\begin{array}{r}-.008 \\
(.010) \\
{[.114]}\end{array}$ & $\begin{array}{r}-.013 \\
(.018) \\
.016]\end{array}$ & $\begin{array}{r}-.004 \\
(.015) \\
.020]\end{array}$ & $\begin{array}{r}-.002 \\
(.011) \\
{[.033]}\end{array}$ \\
\hline Time use-child & $\begin{array}{r}-.046 \\
(.031) \\
.056]\end{array}$ & $\begin{array}{r}-.021 \\
(.009) \\
{[.091]}\end{array}$ & $\begin{array}{r}-.025 \\
(.023) \\
{[.355]}\end{array}$ & $\begin{array}{r}-.028 \\
(.019) \\
{[.034]}\end{array}$ & $\begin{array}{r}-.009 * \\
(.005) \\
{[.041]}\end{array}$ & $\begin{array}{r}-.017 \\
(.019) \\
{[.242]}\end{array}$ \\
\hline Birth mechanisms & $\begin{array}{r}-.007 \\
(.008) \\
{[.009]}\end{array}$ & $\begin{array}{r}-.013 \\
(.011) \\
{[.056]}\end{array}$ & $\begin{array}{r}-.005 \\
(.005) \\
{[.066]}\end{array}$ & $\begin{array}{c}-.042 * * \\
(.010) \\
{[-.008]}\end{array}$ & $\begin{array}{r}.006 \\
(.006) \\
{[-.027]}\end{array}$ & $\begin{array}{r}-.005 \\
(.005) \\
{[.065]}\end{array}$ \\
\hline Parenting discussions & $\begin{array}{r}-.014 \\
(.019) \\
{[.017]}\end{array}$ & $\begin{array}{r}-.042 \\
(.027) \\
{[.186]}\end{array}$ & $\begin{array}{c}-.014 * * \\
(.007) \\
{[.202]}\end{array}$ & $\begin{array}{r}-.003 \\
(.014) \\
{[.003]}\end{array}$ & $\begin{array}{r}-.004 \\
(.012) \\
{[.018]}\end{array}$ & $\begin{array}{c}-.021 * \\
(.011) \\
. .291]\end{array}$ \\
\hline School fixed effects & $\ldots$ & $\ldots$ & $\ldots$ & $\begin{array}{c}-.145^{* * *} \\
(.052) \\
{[.177]}\end{array}$ & $\begin{array}{r}-.085 * \\
(.050) \\
{[.372]}\end{array}$ & $\begin{array}{c}.106^{* *} \\
(.042) \\
{[-1.501]}\end{array}$ \\
\hline Total & $\begin{array}{c}-.735 * * \\
(.104) \\
{[.897]}\end{array}$ & $\begin{array}{r}-.109 \\
(.081) \\
{[.478]}\end{array}$ & $\begin{array}{c}-.167 * * \\
(.070) \\
{[2.370]}\end{array}$ & $\begin{array}{c}-.789 * * \\
(.100) \\
{[.964]}\end{array}$ & $\begin{array}{c}-.204 * * \\
(.082) \\
{[.893]}\end{array}$ & $\begin{array}{r}-.087 \\
(.075) \\
{[1.231]}\end{array}$ \\
\hline Baseline gap & $\begin{aligned}-.819 \\
(.082)\end{aligned}$ & $\begin{array}{l}-.228 \\
(.056)\end{array}$ & $\begin{array}{l}-.071 \\
(.037)\end{array}$ & $\begin{array}{r}-.819 \\
(.082)\end{array}$ & $\begin{array}{r}-.228 \\
(.056)\end{array}$ & $\begin{array}{r}-.071 \\
(.037)\end{array}$ \\
\hline
\end{tabular}

Note.-Standard errors are in parentheses. Numbers in brackets are the share of the baseline gap explained by the group of covariates. Dependent variables are the normalized Add Health version of the Peabody Picture Vocabulary Test, demeaned course-level GPA, and log wages at wave IV. All regressions include child age, and GPA regressions include course-byyear fixed effects for math GPA. White and white mom are omitted. Characteristics are listed in the note to table 7 .

* Significant at the 10 percent level.

** Significant at the 5 percent level.

Three additional issues remain. The first is measurement error in our race variables. Below we use alternative measures of student race and show that our qualitative results hold. Second, differences could be driven by discrimination based on skin tone, as children with white mothers are likely to have lighter skin. We show that results for skin tone follow the same patterns as the results for own race: big effects for skin tone when mother's race is not in the set of controls and small or no effects when mother's race is in the set of controls. The final issue is small sample sizes for interracial families. While we obviously cannot increase the size of the Add Health data, we can improve precision by putting more structure on the model. In particular, rather than viewing each outcome in isolation, we estimate a joint model of all our outcome measures and impose some structure on the relationship between the covariates across the different outcomes.

\section{A. Measurement Error}

Given that multiracial families are identified from measures of race that are self-reported, measurement error may be a concern. Measurement error could manifest itself in at least two ways. First, individuals may choose 
to identify with a group in a way that does not match our standard definitions of race. If this is done by students, we would suspect that mixedrace students might identify with groups that hold values more like theirs. In this case, identifying as black could be correlated with identifying with a lower-achieving group. ${ }^{33}$ This would lead to negative effects of own race for blacks, effects we see little evidence of in our results. On the other hand, if it is the mother identifying with a particular racial group (e.g., if a mixed-race mother identifies herself as black), then mother's race is picking up the cultural environment with which the parent identifies, exactly the effects we hope to pick up by controlling for race of the mother.

Second, measurement error may manifest itself through random misreporting. Suppose that race of the mother and race of the child are noisy measures of the same underlying factor. If children are more likely than their mothers to misreport, then more weight will be placed on the race of the mother. If this bias were large, we would expect changes in the maternal race coefficients when using a measure of child race that is less error-laden.

To address this issue, we use interviewer reports of the child's race. Classification by interviewers included white, black/African American, and other races. ${ }^{34}$ This classification misses Hispanics, who could be assigned to a number of these groups.

In table 12, we report the cross-tab of adolescent self-reported race with the interviewer-reported race (white, black, or other), first for the entire sample and then by maternal race. The full-sample data show that reports differ mainly for Hispanics. Very few individuals show up in the reverse categories for black and white, suggesting that improper self-reporting is not driving the results above. In fact, for non-Hispanic respondents, 0.35 percent of interviewer-reported blacks and 0.36 percent of interviewer-reported whites self-report as the opposite race, suggesting that this is the percentage of individuals making a reporting error. In panel B, we see that 93 of the 123 self-reported black students from white mothers are identified by the interviewer as black.

To have as close to an error-free measure of child race as possible, we restrict our sample to cases in which the interviewer's report of the student's race matches the student's report, using observations along the diagonals of table 12. We therefore do not include individuals who selfreport as Hispanic in the results that follow.

Table 13 gives regression results for two subsamples. In column 1 are results for black students with either black or white mothers as well as white

\footnotetext{
${ }^{33}$ Add Health is one of the few data sets that allow mixed-race respondents to choose multiple races. This form of measurement error could bias our results only if a sizable number of mixed-race adolescents marked only white. If they mark white and black or black, they are designated black in our classification scheme.

${ }^{34}$ The exact question from the survey is "Interviewer: Please code the race of the respondent from your own observation alone: 1) White 2) Black/African American 3) American Indian/Native American 4) Asian/Pacific Islander 5) Other."
} 
TABLE 12

INTERVIEWER-REPORTED RACE SAMPLE

\begin{tabular}{|c|c|c|c|c|}
\hline & \multicolumn{3}{|c|}{ Interviewer-Reported Race } & \multirow[b]{2}{*}{ Total } \\
\hline & White & Black & Other & \\
\hline & \multicolumn{4}{|c|}{ A. Full Sample: Child-Reported Race } \\
\hline White & 7,854 & 11 & 49 & 7,914 \\
\hline Black & 29 & 2,901 & 17 & 2,947 \\
\hline Hispanic & 1,356 & 96 & 883 & 2,335 \\
\hline \multirow[t]{2}{*}{ Total } & 9,239 & 3,008 & 949 & 13,196 \\
\hline & \multicolumn{4}{|c|}{ B. White Mother: Self-Reported Race } \\
\hline White & 7,777 & 4 & 48 & 7,829 \\
\hline Black & 22 & 93 & 8 & 123 \\
\hline Hispanic & 219 & 4 & 83 & 306 \\
\hline \multirow[t]{2}{*}{ Total } & 8,018 & 101 & 139 & 8,258 \\
\hline & \multicolumn{4}{|c|}{ C. Black Mother: Self-Reported Race } \\
\hline White & 6 & 7 & 0 & 13 \\
\hline Black & 6 & 2,780 & 8 & 2,794 \\
\hline Hispanic & 2 & 27 & 6 & 35 \\
\hline \multirow[t]{2}{*}{ Total } & 14 & 2,814 & 14 & 2,842 \\
\hline & \multicolumn{4}{|c|}{ D. Hispanic Mother: Self-Reported Race } \\
\hline White & 71 & 0 & 1 & 72 \\
\hline Black & 1 & 28 & 1 & 30 \\
\hline Hispanic & 1,135 & 65 & 794 & 1,994 \\
\hline Total & 1,207 & 93 & 796 & 2,096 \\
\hline
\end{tabular}

Note.-Interviewer assessment that child's race is white or black must agree with self-report. Maternal race is self-reported.

students, conditioning on agreement of self-reported and interviewerreported race. The same patterns emerge as in the previous tables. Namely, we see no significant negative effects of the student's race being black for male PVT scores, math grades, and log wages, nor do we see negative and significant own-race effects for female PVT scores. However, having a black mother is associated with worse outcomes along all these dimensions of around the same magnitudes as those presented in table 7. In column 2, we further restrict the sample to only those who have white mothers. Again we find no significantly negative effects of own race.

\section{B. Skin Tone}

Another check on whether the self-reporting of race is driving the findings above is to examine skin tone. The difference between the own-race and maternal race coefficients in table 7 is identified from multiracial families. One potential channel for these effects is that there is less discrimination against children from multiracial families, perhaps because they 
TABLE 13

Outcome Gaps among Alternative Subsamples

\begin{tabular}{lcc}
\hline & \multicolumn{2}{c}{ Subsample } \\
\cline { 2 - 3 } Male Outcome & Blacks and Whites & White Mothers \\
\hline AHPVT: & -.100 & -.109 \\
Black & $(.127)$ & $(.129)$ \\
& $-.429^{* *}$ & $\ldots$ \\
Black mom & $(.143)$ & 4,061 \\
Observations & 5,080 & .037 \\
Wages: & .059 & $(.111)$ \\
Black & $(.114)$ & $\ldots$ \\
Black mom & $-.254^{*}$ & 3,710 \\
Observations & $(.135)$ & $.222^{*}$ \\
Math GPA: & 4,480 & $(.125)$ \\
Black & $.240^{*}$ & $\ldots$ \\
Black mom & $(.122)$ & \\
Observations & $-.465^{* *}$ & 8,758 \\
AHPV-females: & $(.135)$ & -.006 \\
Black & 10,702 & -.133 \\
Black mom & -.074 & $\ldots$ \\
Observations & $(.108)$ & 3,710 \\
Mother's characteristics & $-.387^{* *}$ & Yes \\
Father's characteristics & $(.124)$ & Yes \\
School fixed effects & 5,670 & Yes \\
\hline Note. & Yes & Yes \\
\hline
\end{tabular}

Note.-AHPVT and GPA always include controls for female and age; GPA regressions also include course-by-year indicators. All regressions include child age and wave of survey. Wage and completed education regressions come from wave IV. Standard errors are clustered at the school level for wage, education, and AHPVT results and at the individual level for GPA results. The column labeled Blacks and Whites includes only blacks with black mothers, whites with white mothers, and blacks with white mothers.

* Significant at the 10 percent level.

** Significant at the 5 percent level.

more frequently have a lighter skin tone.$^{35}$ The Add Health data collectors described the respondent's skin color in wave III as "Black, Dark brown, Medium brown, Light brown or White." ${ }^{36}$ Since this assessment may be subjective, we also include information on interviewer race. ${ }^{37}$

${ }^{35}$ Rangel (2015) examines this question in Brazil and finds differential investment among children within the same family but with different skin colors. Using data from the 1910 census, Mill and Stein (2012) find little difference in literacy rates between mulatto and black siblings, suggesting that investment rates are fairly similar across skin color.

36 The question interviewers answered was "What is the respondent's skin color: 1) Black 2) Dark brown 3) Medium brown 4) Light brown 5) White?"

${ }^{37}$ Patterns look identical when using interviewer fixed effects as well, though the sample size shrinks. 
A cross-tab of skin tone and maternal race is given in table 14, which shows that the lighter-skinned categories contain a significant number of Hispanics and those of other races. In the lower panel, we present the distribution of skin tone for self-identified blacks, split by maternal race. There is substantial overlap in the distribution, with roughly 30 percent of each group having a "medium brown" skin tone and "light brown" and "dark brown" groups also having nontrivial overlap. Nonetheless, the distribution is shifted toward lighter skin tones for blacks with white mothers.

Table 15 takes table 7 and replaces self-identified race with interviewerreported skin tone and adds controls as before. In the first set of columns that do not include mother's race, we see that darker individuals have lower PVT scores, math grades, and log wages. Adding controls, particularly mother's race, substantially reduces the estimated effects of skin tone. Darker skin is still associated with significantly lower test scores, but its magnitude is reduced by roughly 65 percent for each skin tone group.

In table 16, we present the decomposition of the skin tone gaps. As in the previous decompositions, maternal race is the largest contributor to the PVT score gap, explaining 50-60 percent of the differences in test scores between each skin tone group and those with white skin. Maternal race explains 40 percent of the wage gap for individuals with the darkest skin tone. Overall, the set of controls we introduce explains the vast majority of the outcome gaps for medium- and dark-skinned individuals in our sample (decompositions for light-skinned respondents are in App. table A4). With respect to the wage estimates, one plausible channel for the lack of wage penalties among those blacks raised by white mothers is less discrimination based on skin tone. However, our results do not support this hypothesis. Rather, the decomposition indicates that skin tone is important to wages through its correlation with maternal race.

TABLE 14

Cross-Tabulation of Student Skin Tone and Maternal Race

\begin{tabular}{|c|c|c|c|c|c|}
\hline & \multirow{2}{*}{$\begin{array}{c}\text { White Skin } \\
\text { Tone }\end{array}$} & \multicolumn{3}{|c|}{ Brown Skin Tone } & \multirow[b]{2}{*}{ Total } \\
\hline & & Light & Medium & Dark/Black & \\
\hline \multicolumn{6}{|l|}{ Maternal race: } \\
\hline White & 6,706 & 337 & 83 & 38 & 7,164 \\
\hline Black & 10 & 311 & 772 & 1,383 & 2,476 \\
\hline Hispanic & 824 & 625 & 200 & 72 & 1,721 \\
\hline Total & 7,540 & 1,273 & 1,055 & 1,493 & 11,361 \\
\hline \multicolumn{6}{|l|}{ Black students: } \\
\hline Black mom & 6 & 295 & 767 & 1,356 & 2,424 \\
\hline Percentage & .3 & 12.2 & 31.6 & 55.9 & 100.0 \\
\hline Nonblack mom & 14 & 48 & 32 & 26 & 120 \\
\hline Percentage & 11.7 & 40.0 & 26.7 & 21.7 & 100.0 \\
\hline
\end{tabular}

Note.-Skin tone is reported by the interviewer at wave III; race is self-reported from wave I. 


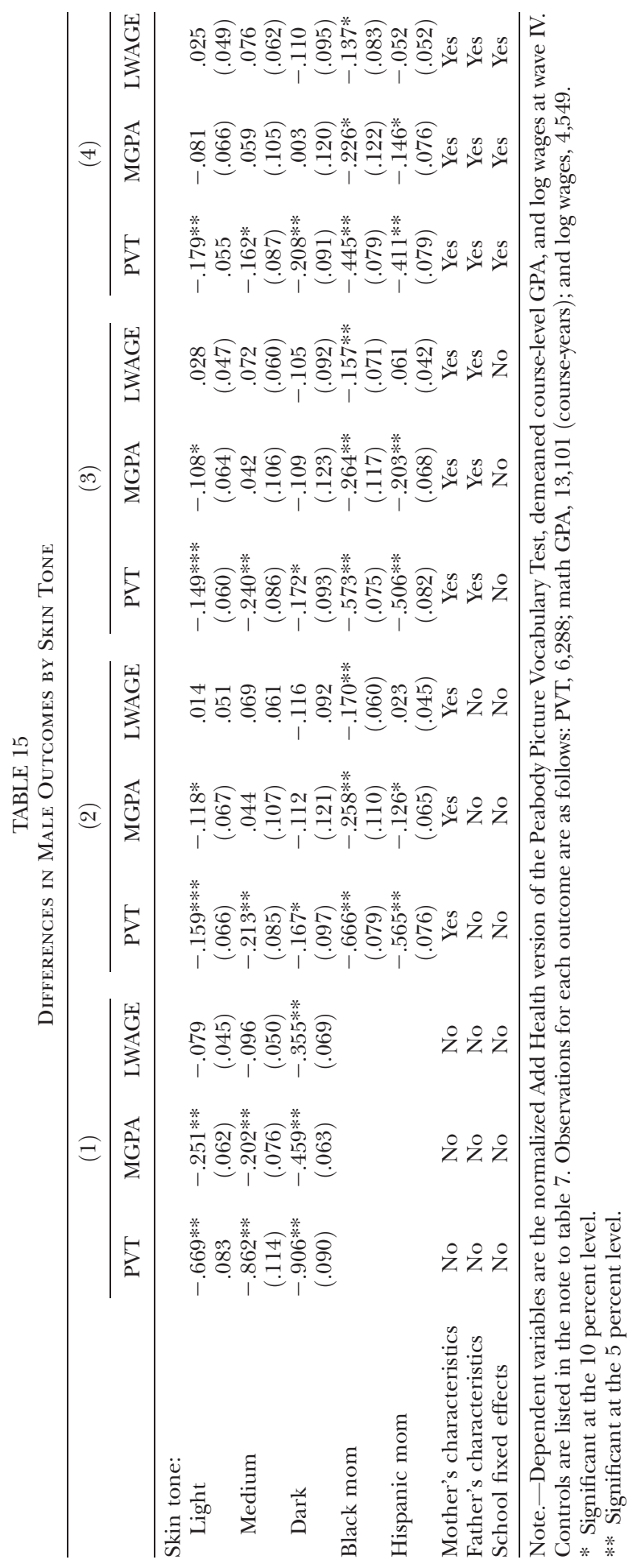


TABLE 16

Decomposition of Male Outcomes by Skin Tone

\begin{tabular}{|c|c|c|c|c|c|c|}
\hline & \multicolumn{3}{|c|}{$\begin{array}{l}\text { Outcome without } \\
\text { School Fixed Effects }\end{array}$} & \multicolumn{3}{|c|}{$\begin{array}{c}\text { Outcome with } \\
\text { School Fixed Effects }\end{array}$} \\
\hline & PVT & MGPA & LWAGE & PVT & MGPA & LWAGE \\
\hline & \multicolumn{6}{|c|}{ A. Medium Skin Tone } \\
\hline $\begin{array}{l}\text { Mother's characteristics, } \\
\text { not race }\end{array}$ & $\begin{array}{c}-.128 * * \\
(.029) \\
.1471\end{array}$ & $\begin{array}{c}-.045^{* *} \\
(.022) \\
{[.223]}\end{array}$ & $\begin{array}{c}-.065^{* *} \\
(.019) \\
{[.674]}\end{array}$ & $\begin{array}{c}-.094 * * \\
(.022) \\
.108]\end{array}$ & $\begin{array}{c}-.034 \\
(.021) \\
.170]\end{array}$ & $\begin{array}{c}-.051 * * \\
(.016) \\
.532]\end{array}$ \\
\hline Mother's race & $\begin{array}{c}-.424 * * \\
(.057) \\
{[.489]}\end{array}$ & $\begin{array}{c}-.184 * * \\
(.067) \\
{[.909]}\end{array}$ & $\begin{array}{c}-.064 \\
(.039) \\
{[.663]}\end{array}$ & $\begin{array}{c}-.333 * * \\
(.055) \\
{[.384]}\end{array}$ & $\begin{array}{c}-.151 * * \\
(.070) \\
{[.749]}\end{array}$ & $\begin{array}{c}-.092 * * \\
(.044) \\
{[.961]}\end{array}$ \\
\hline Father's characteristics & $\begin{array}{c}-.074^{*} \\
(.039) \\
{[.086]}\end{array}$ & $\begin{array}{c}-.015 \\
(.028) \\
{[.074]}\end{array}$ & $\begin{array}{c}-.041 * * \\
(.020) \\
{[.431]}\end{array}$ & $\begin{array}{c}-.041 \\
(.028) \\
{[.048]}\end{array}$ & $\begin{array}{c}.011 \\
(.028) \\
{[-.055]}\end{array}$ & $\begin{array}{c}-.044 * * \\
(.019) \\
{[.459]}\end{array}$ \\
\hline School fixed effects & & & $\ldots$ & $\begin{array}{c}-.236 * * \\
(.093) \\
{[.273]}\end{array}$ & $\begin{array}{r}-.087^{*} \\
(.047) \\
{[.430]}\end{array}$ & $\begin{array}{c}.004 \\
(.026) \\
{[-.043]}\end{array}$ \\
\hline Total & $\begin{array}{l}-.626^{* *} \\
(.080)\end{array}$ & $\begin{array}{l}-.244^{* *} \\
(.071)\end{array}$ & $\begin{array}{l}-.170 * * \\
(.040)\end{array}$ & $\begin{array}{l}-.704^{* *} \\
(.105)\end{array}$ & $\begin{array}{l}-.261^{* *} \\
(.078)\end{array}$ & $\begin{array}{l}-.184^{* *} \\
(.044)\end{array}$ \\
\hline \multirow[t]{2}{*}{ Baseline gap } & $\begin{array}{c}{[.723]} \\
-.866^{* *} \\
(.115) \\
\end{array}$ & $\begin{array}{c}{[1.206]} \\
-.202 * * \\
(.076)\end{array}$ & $\begin{array}{c}{[1.768]} \\
-.096^{* *} \\
(.049) \\
\end{array}$ & $\begin{array}{c}{[.813]} \\
-.866^{* *} \\
(.115)\end{array}$ & $\begin{array}{c}{[1.294]} \\
-.202^{* *} \\
(.076)\end{array}$ & $\begin{array}{c}{[1.909]} \\
-.096^{*} \\
(.049)\end{array}$ \\
\hline & \multicolumn{6}{|c|}{ B. Dark Skin Tone } \\
\hline $\begin{array}{l}\text { Mother's characteristics, } \\
\text { not race }\end{array}$ & $\begin{array}{c}-.116^{* *} \\
(.025) \\
{[.127]}\end{array}$ & $\begin{array}{c}-.061^{* *} \\
(.029) \\
{[.133]}\end{array}$ & $\begin{array}{c}-.061 * * \\
(.023) \\
{[.172]}\end{array}$ & $\begin{array}{c}-.082 * * \\
(.024) \\
{[.091]}\end{array}$ & $\begin{array}{c}-.041 \\
(.028) \\
{[.089]}\end{array}$ & $\begin{array}{c}-.051 * * \\
(.022) \\
{[.145]}\end{array}$ \\
\hline Mother's race & $\begin{array}{c}-.517 * * \\
(.070) \\
{[.569]}\end{array}$ & $\begin{array}{c}-.240^{* *} \\
(.107) \\
{[.523]}\end{array}$ & $\begin{array}{c}-.140 * * \\
(.062) \\
{[.395]}\end{array}$ & $\begin{array}{c}-.402 * * \\
(.073) \\
{[.442]}\end{array}$ & $\begin{array}{r}-.206^{*} \\
(.112) \\
{[.449]}\end{array}$ & $\begin{array}{c}-.142 * * \\
(.073) \\
{[.399]}\end{array}$ \\
\hline Father's characteristics & $\begin{array}{c}-.103^{*} \\
(.065) \\
{[.114]}\end{array}$ & $\begin{array}{c}-.049 \\
(.038) \\
{[.107]}\end{array}$ & $\begin{array}{c}-.047^{*} \\
(.028) \\
{[.133]}\end{array}$ & $\begin{array}{c}-.054 \\
(.041) \\
{[.059]}\end{array}$ & $\begin{array}{c}-.007 \\
(.038) \\
{[.016]}\end{array}$ & $\begin{array}{c}-.052^{* *} \\
(.027) \\
{[.147]}\end{array}$ \\
\hline School fixed effects & - Zео & $\ldots$ & $\ldots$ & $\begin{array}{c}-.162 * * \\
(.048) \\
{[.179]}\end{array}$ & $\begin{array}{c}-.208 * * \\
(.048) \\
{[.453]}\end{array}$ & $\begin{array}{c}-.014 \\
(.038) \\
{[.039]}\end{array}$ \\
\hline Total & $\begin{array}{c}-.736^{* * *} \\
(.093) \\
.810]\end{array}$ & $\begin{array}{c}-.350^{* *} \\
(.107) \\
{[.763]}\end{array}$ & $\begin{array}{c}-.248 * * \\
(.059) \\
.700]\end{array}$ & $\begin{array}{c}-.701 * * \\
(.078) \\
.771]\end{array}$ & $\begin{array}{r}-.462 \\
(.109) \\
{[1.008]}\end{array}$ & $\begin{array}{c}-.259 * * \\
(.063) \\
{[.730}\end{array}$ \\
\hline Baseline gap & $\begin{array}{l}-.0109 * * \\
(.073)\end{array}$ & $\begin{array}{c}-.459 * * \\
(.063)\end{array}$ & $\begin{array}{l}-. .00] \\
-.069 * \\
(.069)\end{array}$ & $\begin{array}{l}-.909 * * \\
(.073)\end{array}$ & $\begin{array}{c}{[1.000]} \\
-.459 \\
(.063)\end{array}$ & $\begin{array}{c}-.355^{* * *} \\
(.069)\end{array}$ \\
\hline
\end{tabular}

Note.-Dependent variables are the normalized Add Health version of the Peabody Picture Vocabulary Test, demeaned course-level GPA, and log wages at wave IV. Controls are listed in the note to table 7 .

* Significant at the 10 percent level.

** Significant at the 5 percent level.

\section{Linking Outcomes}

The final issue with our analysis is small sample sizes, which sometimes result in large standard errors. While we cannot increase our sample, we can place some structure on the problem. So far we have analyzed each outcome independently. It is likely that all these outcomes are influenced 
by common underlying factors related to human capital or discrimination. As a final specification, we consider an "achievement index" that allows each outcome to have a different intercept but constrains the effect of covariates to be proportional across outcomes. Here we include the outcomes in the main analysis (PVT scores, math GPA, and wages) as well as those in the Appendix (overall GPA, science GPA, and college completion). ${ }^{38}$ To the extent that discrimination occurs on the basis of student race, the assumption is that it has the same relative effect as the other covariates across the different outcome measures. Specifically, we estimate a model of male outcomes of the form

$$
\begin{aligned}
Y_{i}= & \lambda_{0 k}+\lambda_{1 k}\left\{\sum_{r} \lambda_{2 r} I\left(\text { Race }_{i}=r\right)+\lambda_{3} X_{1 i}+\lambda_{4} X_{2 i}+\lambda_{5} X_{3 i}\right. \\
& \left.+\left[1-\lambda_{6 k} I(k=\mathrm{GPA})\right] \sum_{j} \lambda_{7 j} I\left(\operatorname{School}_{i}=j\right)\right\}+\varepsilon_{i k},
\end{aligned}
$$

where $\varepsilon_{i k}$ is distributed normally with mean zero and $\operatorname{Var}\left(\varepsilon_{i k}\right)=\sigma_{k}^{2}$. Here, $i$ denotes individual and $k$ denotes outcomes. The outcomes we consider are PVT scores, high school GPA, college attendance, and log wages. The scale parameter for PVT scores, $\lambda_{1, \mathrm{AHPVT}}$, is normalized to one, as is the variance of college graduation, $\sigma_{\text {col }}^{2}$. We allow the school fixed effects to operate differently for grades than the other outcomes as grades are a relative measure: better schools may give lower grades conditional on observed characteristics but nonetheless produce more human capital.

Selected coefficients for the model outlined in equation (8) are presented in table $17 .{ }^{39}$ Across the three columns, the models vary by the sets of controls we include. In model 1 , the only additional controls besides own race are course-by-year fixed effects for the GPA outcomes; in model 2, we add maternal and paternal characteristics; and in model 3, we add school fixed effects. The coefficients for maternal race can be interpreted as the effects on PVT scores in standard deviation units, and multiplying them by the relevant $\lambda_{1 k}$ parameter gives the average effect for the other outcomes. The estimates from model 3 are directly comparable to the gaps presented in the final sets of columns in table 7.

With the additional structure, the standard errors on the coefficients for own-race black or Hispanic fall when compared to the boys panel in table 7 . The coefficients on both own-race variables are small, positive, and insignificant. In contrast, the coefficients on maternal race variables are very large, negative, and statistically significant. The estimates of the ownrace and maternal race parameters confirm the results of prior specifications but offer greater precision. ${ }^{40}$

\footnotetext{
38 Our analysis includes all valid observations, implying that we have an unbalanced panel. Using individuals who had valid observations for each outcome produces very similar results.

39 The table shows results using the Add Health weights. Unweighted results produced similar patterns.

${ }^{40}$ We also estimated specifications on the subsample of blacks with white mothers and whites with white mothers, using the full model. Results are very similar: near-zero own-race coefficients and large and significant maternal race coefficients.
} 
TABLE 17

Full Factor Model of Achievement and Wages

\begin{tabular}{|c|c|c|c|}
\hline & \multicolumn{3}{|c|}{ Model } \\
\hline & (1) & $(2)$ & (3) \\
\hline Black & $\begin{array}{c}-.218 * \\
(.145)\end{array}$ & $\begin{array}{c}.022 \\
(.084)\end{array}$ & $\begin{array}{c}.044 \\
(.047)\end{array}$ \\
\hline Hispanic & $\begin{array}{c}-.213^{* *} \\
(.079)\end{array}$ & $\begin{array}{r}-.004 \\
(.052)\end{array}$ & $\begin{array}{c}.049 \\
(.030)\end{array}$ \\
\hline Black mom & $\begin{array}{c}-.748^{* *} \\
(.160)\end{array}$ & $\begin{array}{c}-.562^{* * *} \\
(.103)\end{array}$ & $\begin{array}{c}-.470 * * \\
(.097)\end{array}$ \\
\hline Hispanic mom & $\begin{array}{c}-.464^{* *} \\
(.107)\end{array}$ & $\begin{array}{c}-.248 * * \\
(.061)\end{array}$ & $\begin{array}{c}-.290 * * \\
(.046)\end{array}$ \\
\hline Mom high school graduate & & $\begin{array}{l}.130 * * \\
(.058)\end{array}$ & $\begin{array}{l}.136 * * \\
(.030)\end{array}$ \\
\hline Mom some college & & $\begin{array}{l}.258 * * \\
(.061)\end{array}$ & $\begin{array}{l}.221 * * \\
(.052)\end{array}$ \\
\hline Mom college graduate & & $\begin{array}{l}.332 * * \\
(.066)\end{array}$ & $\begin{array}{l}.302^{* * *} \\
(.067)\end{array}$ \\
\hline Mom $>$ college graduate & & $\begin{array}{l}.511 * * \\
(.088)\end{array}$ & $\begin{array}{l}.515^{* *} \\
(.053)\end{array}$ \\
\hline Dad high school graduate & & $\begin{array}{c}.029 \\
(.058)\end{array}$ & $\begin{array}{c}.037 \\
(.062)\end{array}$ \\
\hline Dad some college & & $\begin{array}{l}.197 * * \\
(.049)\end{array}$ & $\begin{array}{l}.222 * * \\
(.026)\end{array}$ \\
\hline Dad college graduate & & $\begin{array}{l}.111 * * \\
(.048)\end{array}$ & $\begin{array}{l}.111 * * \\
(.038)\end{array}$ \\
\hline Income & & $\begin{array}{l}.008^{* *} \\
(.003)\end{array}$ & $\begin{array}{l}.011 * * \\
(.003)\end{array}$ \\
\hline Single mom & & $\begin{array}{r}-.085^{*} \\
(.044)\end{array}$ & $\begin{array}{c}-.077 * \\
(.041)\end{array}$ \\
\hline$\lambda_{1, \text { wage }}$ & $\begin{array}{l}.214^{* * *} \\
(.050)\end{array}$ & $\begin{array}{l}.347^{* *} * \\
(.036)\end{array}$ & $\begin{array}{l}.353 * * \\
(.048)\end{array}$ \\
\hline$\lambda_{1, \mathrm{col}}$ & $\begin{array}{l}.592 * * \\
(.071)\end{array}$ & $\begin{array}{l}1.510^{* * *} \\
(.131)\end{array}$ & $\begin{array}{l}1.779 * * \\
(.225)\end{array}$ \\
\hline$\lambda_{1, \mathrm{GPA}}$ & $\begin{array}{l}.458 * * \\
(.070)\end{array}$ & $\begin{array}{l}.626^{* * *} \\
(.066)\end{array}$ & $\begin{array}{l}.632^{* * *} \\
(.040)\end{array}$ \\
\hline$\lambda_{1, \text { SciGPA }}$ & $\begin{array}{l}.467 * * \\
(.063)\end{array}$ & $\begin{array}{l}.648^{* * *} \\
(.069)\end{array}$ & $\begin{array}{l}.699 * * \\
(.075)\end{array}$ \\
\hline$\lambda_{1, \text { MathGPA }}$ & $\begin{array}{l}.667^{* *} \\
(.078)\end{array}$ & $\begin{array}{l}.903 * * \\
(.084)\end{array}$ & $\begin{array}{l}.957 * * \\
(.055)\end{array}$ \\
\hline$\lambda_{6, \mathrm{GPA}}$ & & & $\begin{array}{c}-9.959 * * \\
(.418)\end{array}$ \\
\hline$\lambda_{6, \text { SciGPA }}$ & & & $\begin{array}{c}-8.777 * * \\
(.584)\end{array}$ \\
\hline$\lambda_{6, \text { MathGPA }}$ & & & $\begin{array}{c}-9.900 * * \\
(.227)\end{array}$ \\
\hline Mom's characteristics & No & Yes & Yes \\
\hline Dad's characteristics & No & Yes & Yes \\
\hline School fixed effects & No & No & Yes \\
\hline
\end{tabular}

Note.-All models 1-3 include six outcomes: AHPVT, college completion, log wages, overall GPA, math GPA, and science GPA. Estimates are based only on male respondents. Sample sizes differ for each outcome: AHPVT, 6,579; overall GPA, 14,884; math GPA, 12,998; science GPA, 11,650; college completion, 5,043; and log wages, 4,549. Standard errors are cluster bootstrapped at the school level, and results are weighted using Add Health weights.

* Significant at the 10 percent level.

** Significant at the 5 percent level. 


\section{Conclusion}

Across a number of academic and early labor market outcomes, observables can fully account for differences in outcomes between black children with white mothers and white children with white mothers. On the basis of observables, white mothers with black children are negatively selected relative to white mothers with white children, suggesting that own race is not important for academic and labor market outcomes. Significant outcome gaps remain, however, between blacks with white mothers and blacks with black mothers. ${ }^{41}$ Using the decomposition in Gelbach (2009), we assign almost half of the test score gap to unobserved factors correlated with mother's race for each race-gender combination analyzed.

This research has implications for how we formulate theories of human capital accumulation and discrimination. Our findings support the contention made by Heckman (2011), among others, that the family environment is of primary importance in generating skill gaps observed later in life. While schools certainly play a role, we estimate that differences across schools account for only 20-30 percent of test score gaps. We also conclude that discrimination based on skin color is no longer the first-order concern. We argue instead that disparate outcomes must be operating through characteristics related to maternal race. Discrimination can still be important but must be operating through channels such as language (Grogger 2011) that differ depending on race of the mother. The clear next step is to further isolate why it is that race of the mother correlates so strongly with education and labor market outcomes.

\section{Appendix}

This appendix (1) documents selection into the sample, (2) shows results with different outcome measures (overall GPA, science GPA, and college completion), and (3) repeats the analysis of table 7 without sample weights.

Table A1 shows descriptive statistics in each wave, both conditional and unconditional on observing race of the mother. Those who persist to wave IV have slightly higher test scores, but this is true for all racial groups. Validation studies show that the wave I PVT score mean conditional on wave III participation was 1.3 percent higher than the average among wave I respondents. ${ }^{42}$ Our wave III sample differs because we require a transcript release in addition to participation in wave III (and a valid maternal race report). Comparing this measure of bias from attrition to our estimates shows that our selection criteria systematically increase test scores, but as shown in the final two rows of table A1, there are not large differences across races or time.

Table A2 gives estimation results for our alternative outcome measures. Overall GPA and science GPA are measured each year for each student enrolled in school during that year. The overall GPA regression controls for indicators of the math

${ }^{41}$ While on demographics these two groups are similar, selection on unobservables may mean that these gaps are overstated.

${ }^{42}$ Wave III and wave IV validation studies are available at http://www.cpc.unc.edu /projects/addhealth/data/guides/. 
TABLE A1

Unweighted Means across Waves

\begin{tabular}{|c|c|c|c|}
\hline & Wave I & Wave III & Wave IV \\
\hline Black & $\begin{array}{l}.217 \\
(.003)\end{array}$ & $\begin{array}{l}.199 \\
(.004)\end{array}$ & $\begin{array}{l}.218 \\
(.003)\end{array}$ \\
\hline Hispanic & $\begin{array}{l}.171 \\
(.003)\end{array}$ & $\begin{array}{l}.157 \\
(.003)\end{array}$ & $\begin{array}{l}.159 \\
(.003)\end{array}$ \\
\hline Other & $\begin{array}{c}.081 \\
(.002)\end{array}$ & $\begin{array}{l}.076 \\
(.002)\end{array}$ & $\begin{array}{c}.070 \\
(.002)\end{array}$ \\
\hline Observations race & 18,906 & 11,540 & 14,788 \\
\hline Mom black & $\begin{array}{c}.201 \\
(.003)\end{array}$ & $\begin{array}{l}.183 \\
(.004)\end{array}$ & $\begin{array}{c}.200 \\
(.004)\end{array}$ \\
\hline Mom Hispanic & $\begin{array}{c}.149 \\
(.003)\end{array}$ & $\begin{array}{l}.135 \\
(.004)\end{array}$ & $\begin{array}{l}.139 \\
(.003)\end{array}$ \\
\hline Mom other & $\begin{array}{c}.067 \\
(.002)\end{array}$ & $\begin{array}{l}.066 \\
(.003)\end{array}$ & $\begin{array}{c}.060 \\
(.002)\end{array}$ \\
\hline Observations mom race & 14,943 & 9,295 & 11,907 \\
\hline PVT & $\begin{array}{c}.028 \\
(.008)\end{array}$ & $\begin{array}{c}.024 \\
(.009)\end{array}$ & $\begin{array}{c}.053 \\
(.008)\end{array}$ \\
\hline PVT_-blacks & $\begin{array}{c}-.389 \\
(.016)\end{array}$ & $\begin{array}{c}-.410 \\
(.021)\end{array}$ & $\begin{array}{r}-.345 \\
(.017)\end{array}$ \\
\hline PVT—mom race observed & $\begin{array}{c}.028 \\
(.008)\end{array}$ & $\begin{array}{c}.057 \\
(.010)\end{array}$ & $\begin{array}{c}.082 \\
(.009)\end{array}$ \\
\hline PVT_-blacks, mom race observed & $\begin{array}{c}-.377 \\
(.018)\end{array}$ & $\begin{array}{c}-.390 \\
(.023)\end{array}$ & $\begin{array}{c}-.332 \\
(.019)\end{array}$ \\
\hline \multicolumn{4}{|l|}{ Weighted PVT means: } \\
\hline PVT & $\begin{array}{c}.048 \\
(.046)\end{array}$ & $\begin{array}{c}.074 \\
(.040)\end{array}$ & $\begin{array}{c}.087 \\
(.042)\end{array}$ \\
\hline PVT_-blacks & $\begin{array}{c}-.524 \\
(.071)\end{array}$ & $\begin{array}{r}-.536 \\
(.060)\end{array}$ & $\begin{array}{c}-.504 \\
(.070)\end{array}$ \\
\hline PVT_mom race observed & $\begin{array}{c}.073 \\
(.047)\end{array}$ & $\begin{array}{c}.101 \\
(.040)\end{array}$ & $\begin{array}{l}.109 \\
(.044)\end{array}$ \\
\hline PVT_-blacks, mom race observed & $\begin{array}{c}-.512 \\
(.077)\end{array}$ & $\begin{array}{c}-.525 \\
(.062)\end{array}$ & $\begin{array}{c}-.503 \\
(.078)\end{array}$ \\
\hline
\end{tabular}

Note.-Wave III data are from the transcript file in Add Health.

level, science level, and year of schooling. ${ }^{43}$ For boys, we see the same patterns as we do with our other outcome measures. Namely, without controls for mother's race, both black and Hispanic students have lower overall and science grades and are less likely to finish college. Once we control for mother's race, regardless of whether we account for school fixed effects, the coefficients on mother's race become small and insignificant. Having a black mother is negatively associated with each outcome. The same is true for Hispanic mothers, but the estimates are imprecise. For girls, the estimates are noisy, though adding controls does shrink the negative own-race effects.

The results in table A3 show that the estimates in table 7 are generally insensitive to whether weights are used. Gaps in PVT scores, math grades, and log wages are associated with the race of the mother, not the race of the child. For girls, similar

${ }^{43}$ From the Add Health codebook, "For each year of course taking, students are assigned to the category that reflects the highest level class they took for one semester or more, regardless of whether or not they received credit for the course. If a student took two different math courses in one year for example (such as Algebra II and Geometry), they are placed in the higher category (i.e., Algebra II)." 


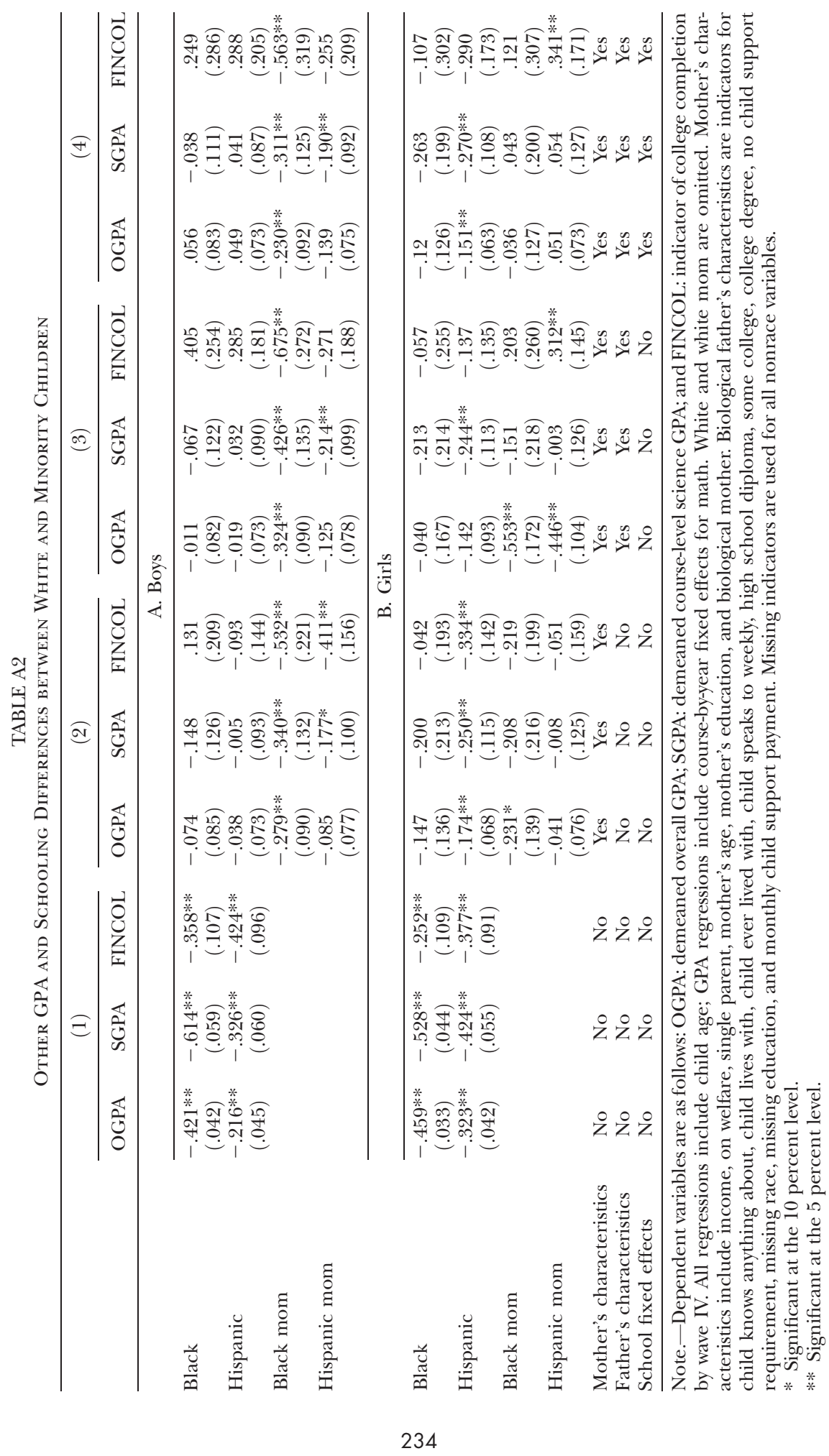




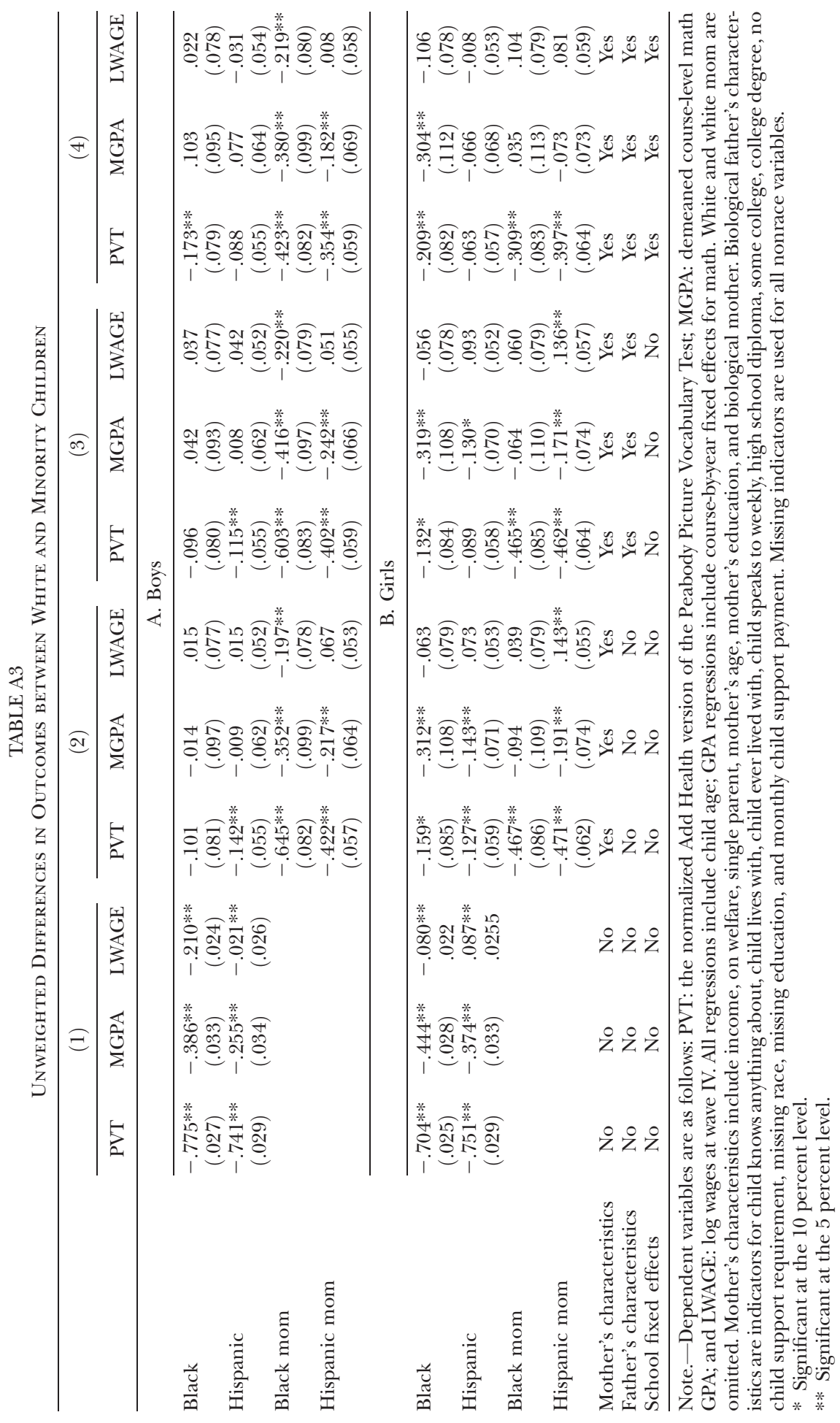


TABLE A4

Decomposition of Male Outcomes for Light Skin Tone

\begin{tabular}{|c|c|c|c|c|c|c|}
\hline \multirow[b]{2}{*}{ Light } & \multicolumn{3}{|c|}{$\begin{array}{l}\text { Outcome without } \\
\text { School Fixed Effects }\end{array}$} & \multicolumn{3}{|c|}{$\begin{array}{l}\text { Outcome with } \\
\text { School Fixed Effects }\end{array}$} \\
\hline & PVT & MGPA & LWAGE & PVT & MGPA & LWAGE \\
\hline $\begin{array}{l}\text { Mother's characteristics, } \\
\text { not race }\end{array}$ & $\begin{array}{c}-.128 * * \\
(.026) \\
{[.193]}\end{array}$ & $\begin{array}{c}-.022 \\
(.019) \\
.0871\end{array}$ & $\begin{array}{c}-.057 * * \\
(.016) \\
{[.721]}\end{array}$ & $\begin{array}{c}-.102 * * \\
(.023) \\
{[.153]}\end{array}$ & $\begin{array}{c}-.014 \\
(.018) \\
.055]\end{array}$ & $\begin{array}{c}-.046^{* * *} \\
(.014) \\
{[.581]}\end{array}$ \\
\hline Mother's race & $\begin{array}{c}-.299 * * \\
(.050) \\
{[.451]}\end{array}$ & $\begin{array}{c}-.118^{* *} \\
(.037) \\
{[.470]}\end{array}$ & $\begin{array}{r}.004^{*} \\
(.024) \\
{[-.047]}\end{array}$ & $\begin{array}{c}-.240 * * \\
(.047) \\
{[.362]}\end{array}$ & $\begin{array}{c}-.089 * * \\
(.039) \\
{[.354]}\end{array}$ & $\begin{array}{r}-.045^{*} \\
(.027) \\
{[.568]}\end{array}$ \\
\hline Father's characteristics & $\begin{array}{c}-.087 * * \\
(.026) \\
{[.131]}\end{array}$ & $\begin{array}{c}-.003 \\
(.024) \\
{[.013]}\end{array}$ & $\begin{array}{c}-.053^{* *} \\
(.013) \\
{[.671]}\end{array}$ & $\begin{array}{l}-.065^{* *} \\
(.024) \\
{[.098]}\end{array}$ & $\begin{array}{r}.006 \\
(.023) \\
{[-.024]}\end{array}$ & $\begin{array}{c}-.052^{* *} \\
(.014) \\
{[.663]}\end{array}$ \\
\hline School fixed effects & . . & $\ldots$ & $\ldots$ & $\begin{array}{c}-.077 * * \\
(.032) \\
{[.116]}\end{array}$ & $\begin{array}{c}-.074^{*} \\
(.040) \\
{[.293]}\end{array}$ & $\begin{array}{c}.035 \\
(.025) \\
{[-.439]}\end{array}$ \\
\hline Total & $\begin{array}{c}-.514 * * \\
(.063) \\
{[.775]}\end{array}$ & $\begin{array}{c}-.143 * * \\
(.040) \\
{[.570]}\end{array}$ & $\begin{array}{r}-.106 \\
(.027) \\
{[1.345]}\end{array}$ & $\begin{array}{c}-.484 * * \\
(.075) \\
{[.729]}\end{array}$ & $\begin{array}{r}-.170 \\
(.054) \\
{[.677]}\end{array}$ & $\begin{array}{c}-.108^{* *} \\
(.033) \\
{[1.373]}\end{array}$ \\
\hline Baseline gap & $\begin{array}{l}-.663^{* *} \\
(.083)\end{array}$ & $\begin{array}{l}-.251 * * \\
(.062)\end{array}$ & $\begin{array}{r}-.079 \\
(.045)\end{array}$ & $\begin{array}{l}-.663 * * \\
(.083)\end{array}$ & $\begin{aligned}-.251 \\
(.062)\end{aligned}$ & $\begin{array}{l}-.079 \\
(.045)\end{array}$ \\
\hline
\end{tabular}

Note.-Dependent variables are the normalized Add Health version of the Peabody Picture Vocabulary Test, demeaned course-level GPA, and log wages at wave IV. Controls are listed in the note to table 7 .

* Significant at the 10 percent level.

** Significant at the 5 percent level.

patterns emerge for PVT scores, with no negative effects associated with race of the mother for wages.

Estimates in table A4 show decompositions for light-skinned individuals, complementing the analysis in table 16 for this group. Maternal race is important in explaining differences in both test scores and grades, but it remains only a sizable predictor of wage gaps for light-skinned individuals when we condition on school fixed effects.

\section{References}

Altonji, Joseph G., Ulrich Doraszelski, and Lewis Segal. 2000. "Black/White Differences in Wealth." Econ. Perspectives 24 (1): 38-50.

Austen-Smith, David, and Roland G. Fryer Jr. 2005. "An Economic Analysis of “Acting White." Q.J.E. 120 (2): 551-83.

Bertrand, Marianne, and Jessica Pan. 2013. "The Trouble with Boys: Social Influences and the Gender Gap in Disruptive Behavior." American Econ. J.: Appl. Econ. 5 (1): 32-64.

Bond, Timothy N., and Kevin Lang. 2013. "The Evolution of the Black-White Test Score Gap in Grades K-3: The Fragility of Results." Rev. Econ. and Statis. 95 (5): 1468-79.

Card, David, and Alan B. Krueger. 1992. "School Quality and Black-White Relative Earnings: A Direct Assessment.” Q.J.E. 107 (1): 151-200. 
Carneiro, Pedro, James J. Heckman, and Dimitriy V. Masterov. 2005. "Labor Market Discrimination and Racial Differences in Premarket Factors." J. Law and Econ. 48 (1): 1-39.

2008. "Understanding the Sources of Ethnic and Racial Wage Gaps and Their Implications for Policy." In Handbook of Employment Discrimination Research, edited by Laura Beth Nielsen and Robert L. Nelson, 99-136. New York: Springer.

Cascio, Elizabeth U., and Douglas O. Staiger. 2012. "Knowledge, Tests, and Fadeout in Educational Interventions." Working Paper no. 18038, NBER, Cambridge, MA.

Chiappori, Pierre-André, Sonia Oreffice, and Climent Quintana-Domeque. 2011. "Black-White Marital Matching: Race, Anthropometrics, and Socioeconomics." IZA Discussion Paper no. 6196, Inst. Study Labor, Bonn.

Cunha, Flavio, James J. Heckman, Lance Lochner, and Dimitriy V. Masterov. 2006. "Interpreting the Evidence on Life Cycle Skill Formation." In Handbook of the Economics of Education, vol. 1, edited by Eric Hanushek and Finis Welch, 697-812. New York: Elsevier.

Currie, Janet M. 2005. "Health Disparities and Gaps in School Readiness." Future of Children 15 (1): 117-38.

Currie, Janet, and Jeffrey Grogger. 2002. "Medicaid Expansions and Welfare Contractions: Offsetting Effects on Prenatal Care and Infant Health?" J. Health Econ. 21 (2): 313-35.

Currie, Janet, and Duncan Thomas. 1999. "The Intergenerational Transmission of 'Intelligence': Down the Slippery Slopes of The Bell Curve." Indus. Relations 38 (3): 297-330.

Eyferth, Klaus. 1961. "Leistungen verschiedener Gruppen von Besatzungskindern in Hamburg-Wechsler Intelligenztest für Kinder (HAWIK)" [Performance of children on the Hamburg-Wechsler intelligence test for children]. Archiv für die gesamte Psychologie 113:222-41.

Ferguson, Ronald F., and Jordana Brown. 2000. "Certification Test Scores, Teacher Quality and Student Achievement." In Analytic Issues in the Assessment of Student Achievement, edited by David W. Grissmer and J. Michael Ross, 133-56. Washington, DC: Nat. Center Educ. Statis.

Flynn, James R. 1999. "Searching for Justice: The Discovery of IQ Gains over Time." American Psychologist 54 (1): 5-20.

Fryer, Roland G., Jr., Lisa Kahn, Steven D. Levitt, and Jörg L. Spenkuch. 2012. "The Plight of Mixed-Race Adolescents." Rev. Econ. and Statis. 94 (3): 621-34.

Fryer, Roland G., Jr., and Steven D. Levitt. 2004. "Understanding the Black-White Test Score Gap in the First Two Years of School." Rev. Econ. and Statis. 86 (2): 447-64.

- 2013. "Testing for Racial Differences in the Mental Ability of Young Children." A.E.R. 103 (2): 981-1005.

Gelbach, Jonah B. 2009. "When Do Covariates Matter? And Which Ones, and How Much?” Working paper, Univ. Arizona.

Grogger, Jeffrey. 2011. "Speech Patterns and Racial Wage Inequality.” J. Human Resources 46 (1): 1-25.

Hanushek, Eric A., and Steven G. Rivkin. 2006. "School Quality and the BlackWhite Achievement Gap.” Working Paper no. 12651, NBER, Cambridge, MA.

Harris, David R., and Justin L. Thomas. 2002. "The Educational Costs of Being Multiracial: Evidence from a National Survey of Adolescents.” Research Report no. 02-521, Population Studies Center, Inst. Soc. Res., Univ. Michigan.

Heckman, James J. 2011. "The American Family in Black and White: A Post-racial Strategy for Improving Skills to Promote Equality." Daedalus 140 (2): 70-89.

Heckman, James J., and Paul A. LaFontaine. 2010. "The American High School Graduation Rate: Trends and Levels." Rev. Econ. and Statis. 92 (2): 244-62. 
Jencks, Christopher, and Meredith Phillips. 1998. The Black-White Test Score Gap. Washington, DC: Brookings Inst.

Jensen, Arthur R. 1998. The g Factor: The Science of Mental Ability. Westport, CT: Praeger.

Mill, Roy, and Luke C. D. Stein. 2012. "Race, Skin Color, and Economic Outcomes in Early Twentieth-Century America." Working paper, Stanford Univ.

Neal, Derek. 2006. "Why Has Black-White Skill Convergence Stopped?" In Handbook of the Economics of Education, vol. 1, edited by Eric Hanushek and Finis Welch, 511-76. New York: Elsevier.

Neal, Derek A., and William R. Johnson. 1996. "The Role of Premarket Factors in Black-White Wage Differences.” J.P.E. 104 (5): 869-95.

Rangel, Marcos A. 2015. "Is Parental Love Colorblind? Human Capital Accumulation within Mixed Families." Rev. Black Polit. Econ. 42 (1/2): 57-86.

Roth, Wendy D. 2005. "The End of the One-Drop Rule? Labeling of Multiracial Children in Black Intermarriages." Sociological Forum 20 (1): 35-67.

Ruebeck, Christopher S., Susan L. Averett, and Howard N. Bodenhorn. 2009. "Acting White or Acting Black: Mixed-Race Adolescents' Identity and Behavior." B. E. J. Econ. Analysis and Policy 9 (1): 1-42.

Ruggles, Steven, J. Trent Alexander, Katie Genadek, Ronald Goeden, Matthew B. Schroeder, and Matthew Sobek. 2010. Integrated Public Use Microdata Series: Version 5.0 [machine-readable database]. Minneapolis: Univ. Minnesota.

Sackett, Paul R., Chaitra M. Hardison, and Michael J. Cullen. 2004. "On Interpreting Stereotype Threat as Accounting for African American-White Differences on Cognitive Tests." American Psychologist 59 (1): 7-13.

Smith, James P., and Finis R. Welch. 1989. "Black Economic Progress after Myrdal." J. Econ. Literature 27 (2): 519-64.

Steele, Claude M., and Joshua Aronson. 1995. "Stereotype Threat and the Intellectual Test Performance of African Americans." J. Personality and Soc. Psychology 69 (5): 797-811.

Todd, Petra E., and Kenneth I. Wolpin. 2007. "The Production of Cognitive Achievement in Children: Home, School, and Racial Test Score Gaps." J. Human Capital 1 (1): 91-136.

US Bureau of Labor Statistics. 2011a. The Employment Situation-August 2011. Washington, DC: Bur. Labor Statis.

_. 2011b. Usual Weekly Earnings of Wage and Salary Workers Second Quarter 2011. Washington, DC: Bur. Labor Statis.

Willerman, Lee, Alfred F. Naylor, and Ntinos C. Myrianthopoulos. 1974. "Intellectual Development of Children from Interracial Matings: Performance in Infancy and at 4 Years." Behavior Genetics 4 (1): 83-90. 
Copyright of Journal of Human Capital is the property of University of Chicago Press and its content may not be copied or emailed to multiple sites or posted to a listserv without the copyright holder's express written permission. However, users may print, download, or email articles for individual use. 